\title{
Foraging ecology of Mediterranean fin whales in a changing environment elucidated by satellite tracking and baleen plate stable isotopes
}

\author{
I. Bentaleb ${ }^{1, *}$, C. Martin ${ }^{1}$, M. $\operatorname{Vrac}^{2}$, B. Mate ${ }^{3}$, P. Mayzaud ${ }^{4}$, D. Siret ${ }^{5}$, \\ R. de Stephanis ${ }^{6,7}$, C. Guinet ${ }^{8}$ \\ ${ }^{1}$ Université Montpellier II, CNRS-ISEM, UMR 5554, 34095 Montpellier, Cedex 5, France \\ ${ }^{2}$ UMR 8212, Laboratoire des Sciences du Climat et de l'Environnement (LSCE-IPSL), CNRS-CEA-UVSQ, \\ 91198 Gif Sur Yvette, France \\ ${ }^{3}$ Marine Mammal Institute, Oregon State University, Newport, OR 97365, USA \\ ${ }^{4}$ Laboratoire d'Océanographie de Villefranche, UMR CNRS 7093, BP. 28, 06230 Villefranche sur Mer, France \\ ${ }^{5} 1$ allée Louis de Villetain, 91190 Gif-sur-Yvette, France \\ ${ }^{6}$ Department of Conservation Biology, Estación Biológica de Doñana, CSIC, C/Americo Vespucio, s/n, 41092, \\ Isla de la Cartuja, Sevilla, Spain
}

${ }^{7}$ CIRCE, Conservation, Information and Research on Cetaceans, c/ Cabeza de Manzaneda 3, Algeciras-Pelayo, 11390 Cadiz, Spain ${ }^{8}$ Centre d'Etudes Biologiques de Chizé, 79360 Villiers-en-Bois, France

\begin{abstract}
We investigated seasonal shifts in diet and distribution of fin whales Balaenoptera physalus occurring in the western Mediterranean Sea. For this purpose, we combined carbon and nitrogen stable isotope ratios $\left(\delta^{13} \mathrm{C}, \delta^{15} \mathrm{~N}\right)$ along 10 baleen plates collected from stranded fin whales between 1975 and 2002 with satellite tag deployments on 11 fin whales during summer 2003. Baleen plate stable isotopes were compared with those of the krill Meganyctiphanes norvegica, the main prey of fin whales in the northwestern Mediterranean Sea. Two plates collected near Malaga, Spain, exhibited larger $\delta^{13} \mathrm{C}$ variations, while only smaller variations could be detected in the other 8 . While all mean baleen plate results were consistent with the $\delta^{13} \mathrm{C}$ signature of Mediterranean $M$. norvegica, the most depleted $\delta^{13} \mathrm{C}$ values were intermediate between those of Atlantic and Mediterranean $M$. norvegica, suggesting westward migrations perhaps extending to the Strait of Gibraltar but not extensive, prolonged feeding in the Northeast Atlantic. This pattern was confirmed by satellite tracking; 1 out of 8 fin whales we successfully tracked left the Mediterranean for the Atlantic. Longer-term changes in isotopic signatures of baleen plates exhibited significant depletion trends, indicating that changes due to increasing input of nutrients and anthropogenic carbon are occurring in the western Mediterranean Sea ecosystem.
\end{abstract}

KEY WORDS: Meganyctiphanes norvegica $\cdot$ Mediterranean Sea $\cdot$ Foraging $\cdot$ Migration $\cdot$ Satellite telemetry $\cdot$ Environmental change

- Resale or republication not permitted without written consent of the publisher

\section{INTRODUCTION}

Fin whales Balaenoptera physalus are the largest marine mammals in the Mediterranean Sea (Notarbartolo di Sciara et al. 2003), with an estimated population of 3500 individuals. B. physalus feed on the krill Meganyctiphanes norvegica (euphausiacea) as revealed both by feces (Orsi Relini \& Giordano 1992) and fatty acid (Ruchonnet et al. 2006) analyses. They gather during summer in the northern part of the western basin (Forcada et al. 1996, Monestiez et al. 2006, Cotté et al. 2009), where they are exposed to shipping collisions, a major threat for the species (Panigada et al. 2006) particularly in the Mediterra- 
nean, which accounts for $30 \%$ (in Notarbartolo di Sciara et al. 2003) of the world's merchant shipping covering only $0.8 \%$ of the global ocean surface. Information about their population distribution outside the summer period is lacking, yet it is needed to develop mitigation measures for the conservation of the species. Mediterranean fin whales are genetically distinct from the other north Atlantic populations (Bérubé et al. 1998). The degree of contact between Mediterranean and Atlantic fin whale populations has been debated for the last 2 centuries, and the prevailing idea is that the stocks are geographically isolated (Notarbartolo di Sciara et al. 2003). Recently, from fin whale sighting and satellite tracking, Cotté et al. (2008) suggested a regional fidelity to the northwestern Mediterranean Sea. Sightings have been recorded in shallow water around Lampedusa Island in winter (Canese et al. 2006), and Aïssi et al (2008) suggested a probable year-round distribution along synchronic seasonal dispatching, with a feeding behaviour occurrence in the Ligurian Sea during late spring and summer and in the Lampedusa area from late winter to early spring. However, the results are still insufficient to prove year-round residency of a large portion of the fin whale Mediterranean population.

In the present study, the distribution of fin whales was investigated by monitoring movement using satellite tags deployed on whales present in the northwestern Mediterranean Sea during summer. This approach was complemented by the measurements of stable isotopes in fin whale tissues, which can be a powerful complement for investigating foraging behaviour, not only in terms of diet but also in terms of movement of marine predators (Kelly 2000, Bearhop et al. 2004, Bailleul et al. 2010). Recently developed methods of diet analysis (e.g. lipids and stable isotopes) are increasingly used to investigate the feeding habits of predator species. The stable isotope ratio for an animal's tissue is often related to that of its diet, with a difference due to the trophic isotopic enrichment factor between dietary and consumer tissue (DeNiro \& Epstein 1978, 1981). Consumer tissues are enriched in ${ }^{15} \mathrm{~N}$ relative to their food, and, consequently, $\delta^{15} \mathrm{~N}$ measurements serve as indicators of a consumer trophic position (McCutchan et al. 2003, Vanderklift \& Ponsard 2003) integrated over months while stomach contents or feces analysis are generally only representative of the very last foraging areas visited. Pioneering studies of DeNiro \& Epstein (1981), Minagawa \& Wada (1984), and Peterson \& Fry (1987) suggested that consumers become enriched in ${ }^{15} \mathrm{~N}$ relative to their food by 3 to $4 \%$. However a num- ber of studies reveal a wider range of isotopic ${ }^{15} \mathrm{~N}$ enrichment between trophic levels (1.7 to $4.5 \%$; Minagawa \& Wada 1984, Abend \& Smith 1997, Post 2002). A mean $3.4 \%$ enrichment value was used by Pinnegar et al. (2003) in their exhaustive western Mediterranean fishery landing study.

In contrast, small increases of $\delta^{13} \mathrm{C}$ between prey and predators are reported in the literature $(<2 \%$, mean $1 \%$ ) (De Niro \& Epstein 1978, Wada et al. 1991) providing clues about the ultimate origin of their food. $\delta^{13} \mathrm{C}$ values of organic tissue along food chain are mainly used to assess consumer foraging areas, i.e. inshore versus offshore, pelagic versus benthic, or latitudinal variations in the contribution to food intake (Kelly 2000, Cherel \& Hobson 2007). The origin of the latitudinal depletion of marine organic matter $\delta^{13} \mathrm{C}$ with increasing latitude has been mainly attributed to changes in the concentration of aqueous $\mathrm{CO}_{2}$ (Rau et al. 1989, Bentaleb et al. 1998). These regional and latitudinal $\delta^{13} \mathrm{C}$ gradients have been also used as an effective way for investigating seasonal change in the foraging areas of marine predators (Cherel \& Hobson 2007, Cherel et al. 2007).

The whale baleen plates are a particularly suitable tissue to investigate the temporal change of the $\delta^{15} \mathrm{~N}$ and $\delta^{13} \mathrm{C}$ due to their continuous growth throughout lifetime (Hobson et al. 2004). The baleen plates grow down from the gums of the upper jaw and are arranged in rows that extend down each side of the mouth. The terminal end continually wears off. The baleens composed of keratinous protein are metabolically inactive after formation (Schell et al. 1989a). Thus, their isotopic composition is believed to record the diet of the whales through its synthesis. Schell et al. $(1989 a, b)$ measured stable isotope ratios in the baleen plates of bowhead whales Balaena mysticetus and found isotopic oscillations along the length of the baleen plates. Similar oscillations were also found in the baleen of southern right whales Eubalaena australis (Best \& Schell 1996). The technique was also successfully applied to investigate seasonal shift in diet of Minke whales off Japan (Mitani et al. 2006) and long-term average diet (Hobson et al., 2004).

The present study focuses on the Mediterranean Balaenoptera physalus (hereafter fin whale). The main objectives of our study were to assess seasonal movements or dietary shift of this population and their movements inside the Mediterranean Sea by combining the information provided by: (1) satellite tracking of individual fin whales marked in the Mediterranean Sea at the end of summer, and (2) analyses of $\delta^{15} \mathrm{~N}$ and $\delta^{13} \mathrm{C}$ signatures along baleen 
plates collected from stranded fin whales in the western Mediterranean, and of krill Meganyctiphanes norvegica (hereafter krill) sampled in the Mediterranean sea and in the Atlantic ocean.

We assert that the isotopic composition of the krill consumed throughout the fin whale lifetime is preserved. Whenever Mediterranean fin whales migrate, or shift preys, they should exhibit corresponding changes in the isotopic signature along their plates. Stable isotope values should be different between different prey or between the Mediterranean Sea and the Atlantic Ocean. Finally, from plates collected from the $1970 \mathrm{~s}$ to the $2000 \mathrm{~s}$, we tried to detect whether $\delta^{13} \mathrm{C}$ and $\delta^{15} \mathrm{~N}$ stable isotope signatures shift over time, revealing some large-scale and long-term environmental change within the Mediterranean Sea.

\section{MATERIALS AND METHODS}

\section{Sampling of materials}

Baleen plates are made of Keratin. They grow from the gums of the upper jaw and are arranged in rows that extend down each side of the mouth. Baleen grows throughout the whale's lifetime; the terminal end continually wears off. The outer (outside-facing) edge of each plate is smooth, while the inner edge is frayed (see Fig. 1). The frayed edge of each plate intertwines to form a mat, which functions as a strainer during filter feeding.

A total of 10 baleen plates (BP) was collected over the period 1975 to 2002 from 9 fin whales stranded along the western Mediterranean coast. Eight BPs were collected on the French coast (BP1 to BP7 and BP9) and 2 in the Malaga area and the Strait of Gibraltar, Andalusia, Spain (BPs 8 and 10). BPs 3 and 4 were collected from the same individual stranded in Port-La-Nouvelle (France). BP3 was collected from the right upper jaw, whereas BP4 was taken in the anterior part (see Fig. 1, Table 1).

Krill from the Atlantic Ocean (between 38 and $45^{\circ} \mathrm{N}$ and 12 and $13^{\circ} \mathrm{W}$ ) was sampled during the POMME 2 and 3 cruises in March and September 2001 using a mid-water trawl. Stable isotopic study concerned a total of 12 adult and sub-adult individuals (6 each for spring and fall), and the 6 adults were sexed (4 males and 2 females; Table 2). Samples were immediately frozen at $-80^{\circ} \mathrm{C}$ (see Salomon et al. 2000) until laboratory analysis. For the Mediterranean Sea, we used stable isotopic data and carbon: nitrogen ratio $(\mathrm{C}: \mathrm{N})$ of 12 adult specimens (6 each from spring and fall) of krill sampled in the Gulf of Lion (Ferraton 2007; Table 3).

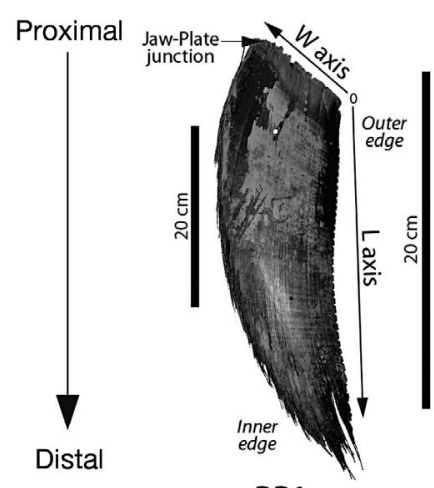

$\mathrm{BP} 1$

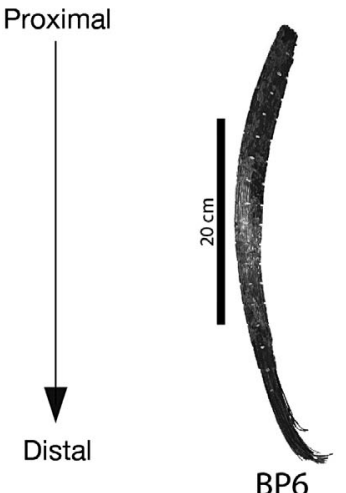

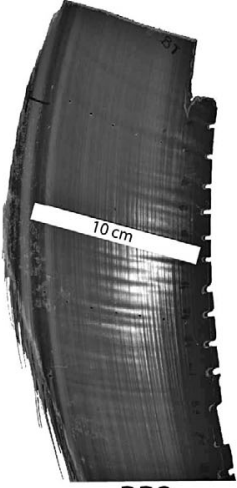

BP2

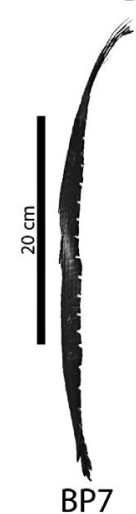

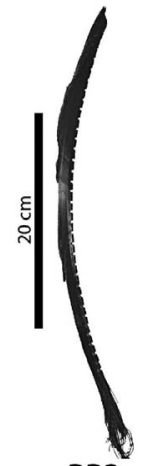

BP3

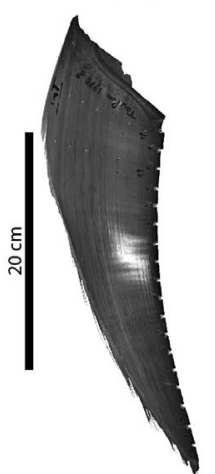

BP8

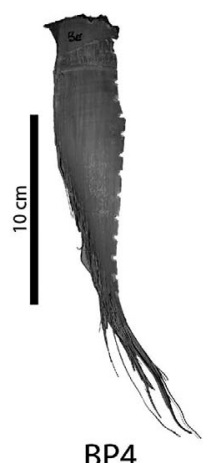

BP4

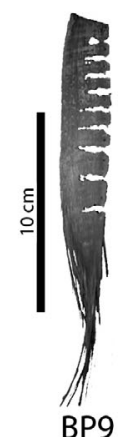

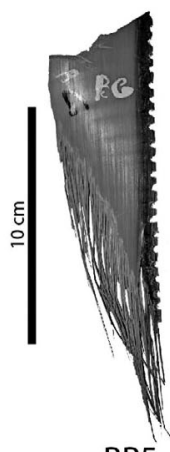

BP5

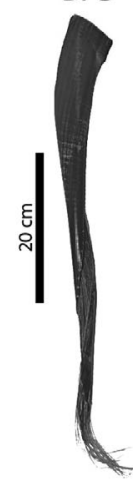

BP10

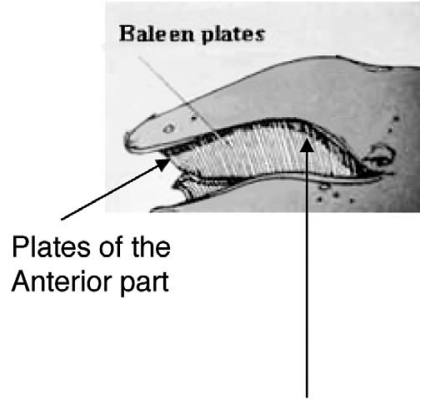

Plates of the left upper jaw

Fig. 1. Balaenoptera physalus. Photographs of the 10 baleen plates (BP) of fin whales stranded along western Mediterranean coasts. Sampling follows the L-axis (proximal $=$ jaw to plate junction, $\mathrm{L}=0$; Distal $=$ Lmax). Some BPs have conserved the junction zone between jaw and plate (see BP1) and have both outer and inner edge. The scale is given on the side of each BP 


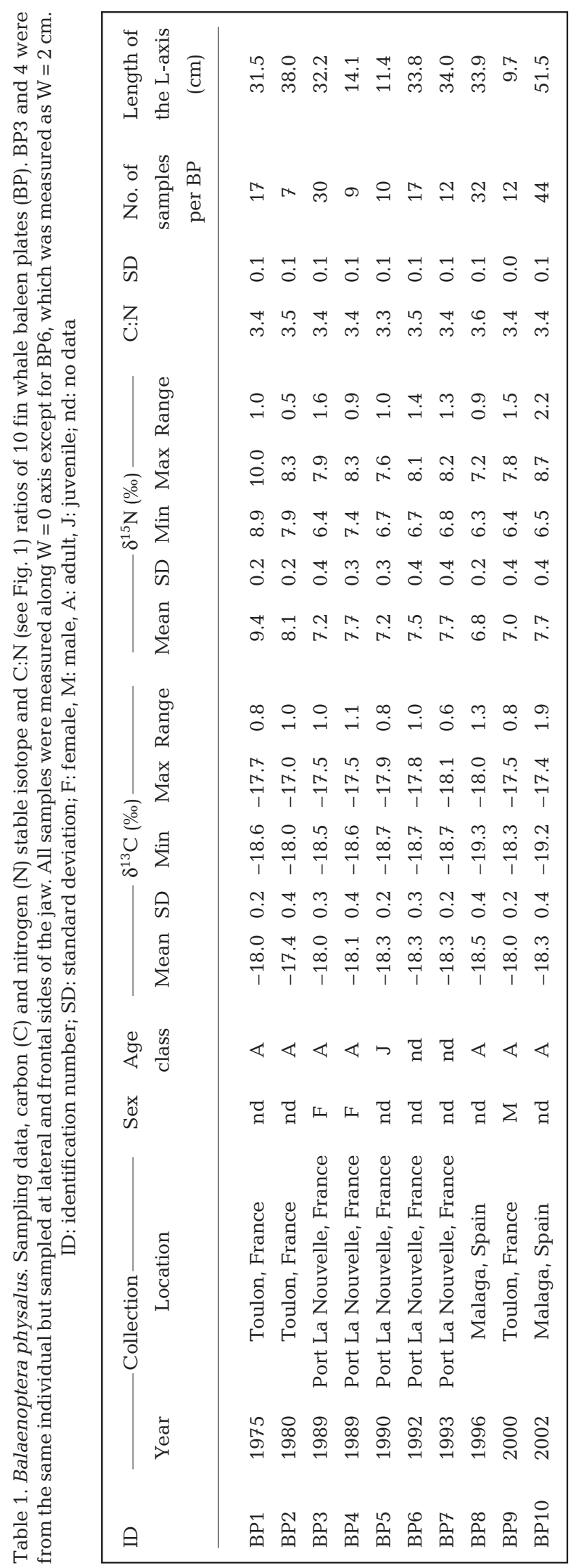

\section{Stable isotope analyses of fin whale baleen plates and krill}

Baleen plates were rinsed with distilled water and dried in an oven at $50^{\circ} \mathrm{C}$. We used a dental drill to collect the keratin powder along the L-axis from the proximal part (below the gum line) to the to the most distal, i.e. oldest part of the plates at an interval of $\sim 1 \mathrm{~cm}$ so as to represent an approximately constant time interval. The drilled area was 2 to $3 \mathrm{~mm}$ in diameter. The sampling took place at the outer edge $(\mathrm{W}=0)$ for most of the plates except BP6 $(\mathrm{W}=2 \mathrm{~cm})$. The plates are generally broken in different areas such as BPs1, 2, 7, and 8, for which an undetermined and probably significant top portion is missing (Fig. 1).

The powder ( 0.5 to $1.0 \mathrm{mg}$ ) was collected in a glass tube previously washed with hydrochloric acid and rinsed with distilled water, and dried at $60^{\circ} \mathrm{C}$ for $48 \mathrm{~h}$. The stable-carbon and stable-nitrogen isotope assays and the $\mathrm{C}$ and $\mathrm{N}$ contents were performed in 2008 at the Institut des Sciences de l'Evolution de Montpellier Laboratory. About 70 to $120 \mu \mathrm{g}$ of homogenized powder samples were loaded into tin cups and combusted at $1200^{\circ} \mathrm{C}$ in a Euro Vector EA3000 elemental analyzer. Resultant $\mathrm{CO}_{2}$ and $\mathrm{N}_{2}$ gases were analyzed by continuous flow using an interfaced GV Optima Isotope Ratio Mass Spectrometer (IRMS). $\delta^{13} \mathrm{C}$ and $\delta^{15} \mathrm{~N}$ values are expressed in $\delta$ notation relative to V-PDB belemnite and atmospheric $\mathrm{N}_{2}$ (air), respectively. The $\delta$ notation represents the deviation from standards in parts per thousand $(\%)$ :

$$
\delta^{13} \mathrm{C} \text { or } \delta^{15} \mathrm{~N}=\left(R_{\text {sample }} / R_{\text {standard }}-1\right) \times 1000
$$

where $R={ }^{13} \mathrm{C} /{ }^{12} \mathrm{C}$ or ${ }^{15} \mathrm{~N} /{ }^{14} \mathrm{~N}$. Replicate $\delta^{15} \mathrm{~N}$ measurements of both potassium nitrate $(\mathrm{n}=36$; IAEANO-3- $\delta^{15} \mathrm{~N}: 4.7 \%$ ) and alanine (ISEM internal standard unknown origin; $\mathrm{n}=41$; alanine- $\delta^{15} \mathrm{~N}$ : $-0.5 \%$ ) indicate a reproducibility better than $0.2 \%$ and an accuracy of $0.1 \%$. Both accuracy and reproducibility of the $\delta^{13} \mathrm{C}$ Nist-8541 graphite (also known as USGS24 with a $\delta^{13} \mathrm{C}$ of $-16.1 \%$; $\mathrm{n}=34$ ) are $0.3 \%$. The alanine $\delta^{13} \mathrm{C}$ accuracy was quite poor $(0.5 \%)$, but the reproducibility was $0.2 \%$. Using the $\mathrm{C}$ and $\mathrm{N}$ contents of the IAEA-NO-3 $(\mathrm{N} \%=13)$, and Alanine $(\mathrm{C} \%=$ $40 \%$ ), the baleen plate $\mathrm{C}$ and $\mathrm{N}$ contents (\%) were measured with a precision of $1 \%$.

Whole Atlantic krill individual samples were lyophilized, powdered using a mortar pestel and sieved through a $60 \mu \mathrm{m}$ mesh. We did not remove the chitin assuming that the small content (3.7 to $5 \%$ of krill dry weight (DW) according to Raymont et al. 1971) will not significantly affect the isotopic value of the whole individual. Moreover it allowed us to compare 
Table 2. Meganyctiphanes norvegica. $\delta^{13} \mathrm{C}, \delta^{15} \mathrm{~N}$, and C: $\mathrm{N}$ values of $12 \mathrm{bulk}$ and 12 lipid free samples of Atlantic krill. Spring, fall, and annual values are mean \pm SD. F: female, M: male; Sub: sub-adult

\begin{tabular}{|c|c|c|c|c|c|c|c|c|}
\hline \multirow[t]{2}{*}{ Sample } & \multirow{2}{*}{$\begin{array}{c}\text { Collection } \\
\text { date }(\mathrm{mo} / \mathrm{yr})\end{array}$} & \multirow[t]{2}{*}{$\mathrm{n}$} & \multicolumn{3}{|c|}{ Bulk samples } & \multicolumn{3}{|c|}{ Lipid-free samples } \\
\hline & & & $\delta^{13} \mathrm{C}$ & $\delta^{15} \mathrm{~N}$ & $\mathrm{C}: \mathrm{N}$ & $\delta^{13} \mathrm{C}$ & $\delta^{15} \mathrm{~N}$ & $C: N$ \\
\hline 1753_5F & 03/2001 & 1 & -20.9 & 5.3 & 3.8 & -20.9 & 6.3 & 3.5 \\
\hline 1753_6F & $03 / 2001$ & 1 & -21.4 & 4.5 & 3.9 & -21.2 & 5.5 & 3.7 \\
\hline 1755_1M & 03/2001 & 1 & -21.5 & 5.7 & 3.7 & -21.4 & 6.0 & 3.6 \\
\hline 1755_2M & $03 / 2001$ & 1 & -20.7 & 6.8 & 3.5 & -20.6 & 7.1 & 3.5 \\
\hline 1755_3M & 03/2001 & 1 & -21.2 & 5.9 & 3.9 & -20.8 & 6.5 & 3.5 \\
\hline 1755_4M & $03 / 2001$ & 1 & -20.7 & 6.6 & 3.5 & -20.7 & 6.7 & 3.5 \\
\hline 1754_SUB6 & 09/2001 & 1 & -21.3 & 7.1 & 3.9 & -21.0 & 7.1 & 3.6 \\
\hline 1756_SUB1 & 09/2001 & 1 & -21.1 & 7.8 & 3.6 & -21.2 & 7.8 & 3.6 \\
\hline 1756_SUB2 & 209/2001 & 1 & -21.2 & 8.4 & 4.0 & -20.9 & 8.6 & 3.7 \\
\hline 1756_SUB3 & 09/2001 & 1 & -21.4 & 7.2 & 3.9 & -21.2 & 7.3 & 3.7 \\
\hline 1756_SUB4 & 109/2001 & 1 & -20.9 & 7.4 & 4.0 & -20.9 & 7.3 & 4.0 \\
\hline 1756_SUB5 & 09/2001 & 1 & -21.7 & 6.9 & 3.8 & -21.4 & 7.2 & 3.5 \\
\hline $\begin{array}{l}\text { Spring mear } \\
\pm \text { SD }\end{array}$ & & 6 & $\begin{array}{r}-21.1 \\
\pm 0.4\end{array}$ & $\begin{array}{c}5.8 \\
\pm 0.9\end{array}$ & $\begin{array}{c}3.7 \\
\pm 0.2\end{array}$ & $\begin{array}{r}-20.9 \\
\pm 0.3\end{array}$ & $\begin{array}{c}6.3 \\
\pm 0.6\end{array}$ & $\begin{array}{l}3.5 \\
\pm 0.1\end{array}$ \\
\hline $\begin{array}{l}\text { Fall mean } \\
\pm \mathrm{SD}\end{array}$ & & 6 & $\begin{array}{r}-21.3 \\
\pm 0.3\end{array}$ & $\begin{array}{c}7.4 \\
\pm 0.6\end{array}$ & $\begin{array}{l}3.8 \\
0.2\end{array}$ & $\begin{array}{r}-21.1 \\
\pm 0.2\end{array}$ & $\begin{array}{c}7.5 \\
\pm 0.6\end{array}$ & $\begin{array}{c}3.7 \\
\pm 0.2\end{array}$ \\
\hline $\begin{array}{l}\text { Annual mea } \\
\pm \mathrm{SD}\end{array}$ & & 12 & $\begin{array}{r}-21.2 \\
\pm 0.3\end{array}$ & $\begin{array}{c}6.6 \\
\pm 1.1\end{array}$ & $\begin{array}{c}3.8 \\
\pm 0.2\end{array}$ & $\begin{array}{r}-21.0 \\
\pm 0.3\end{array}$ & $\begin{array}{c}6.9 \\
\pm 0.8\end{array}$ & $\begin{array}{r}3.6 \\
\pm 0.1\end{array}$ \\
\hline
\end{tabular}

Table 3. Meganyctiphanes norvegica. Spring, fall, and annual values of $\delta^{13} \mathrm{C}$, $\delta^{15} \mathrm{~N}$, and C:N (mean $\pm \mathrm{SD}$ ) of Atlantic Ocean (AO) and Mediterranean Sea (MS) (Ferraton 2007) bulk krill samples

\begin{tabular}{|lccccc|}
\hline Origin, year & Season & $\mathrm{n}$ & $\delta^{13} \mathrm{C}$ & $\delta^{15} \mathrm{~N}$ & $\mathrm{C} / \mathrm{N}$ \\
\hline AO, 2001 & Spring & 6 & $-21.1 \pm 0.4$ & $5.8 \pm 0.9$ & $3.7 \pm 0.2$ \\
(present study) & Fall & 6 & $-21.3 \pm 0.3$ & $7.4 \pm 0.6$ & $3.8 \pm 0.2$ \\
& Annual & 12 & $-21.2 \pm 0.3$ & $6.6 \pm 1.1$ & $3.8 \pm 0.2$ \\
& & & & & \\
MS, 2004 & Spring & 6 & $-19.0 \pm 0.4$ & $4.1 \pm 0.5$ & $5.6 \pm 0.4$ \\
(Ferraton 2007) & Fall & 6 & $-19.7 \pm 0.2$ & $5.0 \pm 0.2$ & $5.7 \pm 0.1$ \\
& Annual & 12 & $-19.3 \pm 0.5$ & $4.4 \pm 0.6$ & $5.6 \pm 0.2$ \\
\hline
\end{tabular}

For the Mediterranean Sea we used stable isotope and $\mathrm{C}: \mathrm{N}$ ratio data for spring and fall Mediterranean krill from Ferraton (2007). We assumed that Ferraton's data were representatitive endmember of $\delta^{13} \mathrm{C}$ and $\delta^{15} \mathrm{~N}$ compositions for the Mediterranean fall and spring krill. High lipid concentration can mask a large part of the $\delta^{13} \mathrm{C}$ isotopic signature because lipids are ${ }^{13} \mathrm{C}$ depleted (6 to $8 \%$ ) compared with proteins and carbohydrates (De Niro \& Epstein 1978, McConnaughey \& McRoy 1979). We tested the effect of the lipid content by comparing the 12 Atlantic Ocean krill C and $\mathrm{N}$ isotopic compositions measured before and after the lipid extraction treatment using cyclohexane. Available Mediterranean krill isotopic data concerns only non-lipid extracted samples.

\section{Satellite tracking}

Semi-implantable tags $(26 \mathrm{~cm}$ in length $\times 1.9 \mathrm{~cm}$ in diameter) consisted of a Telonics Argos ST-15 transmitter in a stainless steel tube, incorporating a flexible $12.5 \mathrm{~cm}$ whip-antenna, a flexible $4 \mathrm{~cm}$ saltwater switch (SWS), and 2 solid flanges $(0.9 \times 1.5 \mathrm{~cm})$ to prevent inward migration. Half of the anterior housing was coated with $2.5 \mathrm{~g}$ of Gentamycin sulfate antibiotic in methacrylate (Eudragrit), designed for extended time-release. The tag was applied to the fin whale using an air-powered applicator (Heide-Jørgensen et al. 2001) with 7 bar pressure from an el-

Atlantic krill isotopic composition values to those of the Mediterranean Sea analysed with chitin intact (Ferraton 2007). The isotopic measurements were performed in the laboratory of Littoral Environnement et Sociétés (LIENS). Precision of the acetanilide is $0.2 \%$ for ${ }^{13} \mathrm{C}$ and ${ }^{15} \mathrm{~N}$, and $\sim 1 \%$ for the $\mathrm{C}$ and $\mathrm{N}$ elemental content. We did not proceed to a crosscalibration of standards. Instead we compared the isotopic results of the 12 bulk Atlantic krill powders analyzed at an interval time of $4 \mathrm{yr}$ in 2009 at LIENS and 2005 at ISEM laboratories. Results show very consistent $\delta^{13} \mathrm{C}$ values (differences <0.1\%o), while ISEM $\delta^{15} \mathrm{~N}$ values were consistently depleted by $0.6 \%$ compared to LIENS. This difference does not affect our interpretation. evated $1 \mathrm{~m}$ bow pulpit at a distance of $<3 \mathrm{~m}$ from a $6 \mathrm{~m}$ outboard-powered boat. Tags were deployed within $2 \mathrm{~m}$ of the dorsal fin frontal part. To conserve batteries and extend tag operation, tags transmitted for only 4 periods of $1 \mathrm{~h}$ daily for $90 \mathrm{~d}$ and then every fourth day. A saltwater switch prevented the tag from transmitting when underwater. At the surface, transmissions were programmed to coincide with optimal satellite coverage within the western Mediterranean Sea.

\section{Statistics}

Data were analyzed statistically using the R language (R Development Core Team 2010). Isotopic 
ratios were means $\pm \mathrm{SD}$, and statistical tests regarding potential differences in variances or means for different sub-groups were performed using FisherSnedecor and Student's $t$-test or Welsh's test (e.g. see Wilks 2006), respectively, at a $95 \%$ level of significance $(\alpha=0.05)$. Statistical analyses performed on BPs in the sections that follow refer always to BPs with $\mathrm{W}=0$, hence excluding BP6 $(\mathrm{W}=2 \mathrm{~cm})$.

\section{RESULTS}

\section{Stable isotopes of krill}

Bulk powders of 12 Atlantic krill individuals sampled in spring $(\mathrm{n}=6$; adults) and fall $(\mathrm{n}=6$; subadults $)$ were analyzed for $\mathrm{C}$ and $\mathrm{N}$ stable isotopes and $\mathrm{C}$ and $\mathrm{N}$ contents (\%) before and after lipid removal by chemical treatment (Table 2). Sample sizes were too small to parse out class age or seasonal effect. Hence seasonal effects cannot be independently studied for the Atlantic krill data.

Using a dependent $t$-test for paired samples, carbon stable isotope values (mean $\pm \mathrm{SD}, \mathrm{n}=12$ ) before $(-21.2 \pm 0.3 \%)$ and after $(-21.0 \pm 0.3 \%$ o $)$ chemical treatment were statistically significantly different $(t=$ $3.1, \mathrm{p}<0.01)$. For the nitrogen isotopic values, significant differences between none lipid extracted (6.6 \pm $1.1 \%$ ) and lipid free samples $(6.9 \pm 0.8 \%$ o) were found $(t=3.06, \mathrm{p}<0.05)$. These statistical analyses suggest an effect of the chemical treatment for carbon and nitrogen isotopic composition of the krill. These delipidation treatments have been discussed in Kiljuenen et al. (2006) and Post et al. (2007).

Lipid removal does cause slight and statistically significant changes in $\delta^{13} \mathrm{C}$ and $\delta^{15} \mathrm{~N}$ values for wholebody krill. However, on the absolute scale the differences in $\delta^{15} \mathrm{~N}$ and $\delta^{13} \mathrm{C}$ between lipid extracted and bulk krill are small, by 0.32 and $0.15 \%$, respectively, on average. Therefore in order to allow direct comparison with the results provided by Ferraton (2007) for Mediterranean krill, bulk krill values were used, for which seasonal $\delta^{13} \mathrm{C}$ and $\delta^{15} \mathrm{~N}$ differences were reported (Table 3). Mean $\delta^{13} \mathrm{C}$ is higher in spring $(-19.0 \pm 0.4 \%)$ than during fall $(-19.7 \pm 0.2 \%)$, and $\delta^{15} \mathrm{~N}$ mean increases from $4.1 \pm 0.5 \%$ in spring to $5.0 \pm 0.1 \%$ in fall.

Significant differences were found between bulk krill sampled in the Atlantic Ocean (AO) and the Mediterranean Sea (MS) at the annual scale for both the $\delta^{13} \mathrm{C}$ (MS: $-19.3 \pm 0.5 \%$; AO: $-21.2 \pm 0.3 \%$; $t=$ $-6.53, \mathrm{p}<0.01)$ and $\delta^{15} \mathrm{~N}(\mathrm{MS}: 4.4 \pm 0.6 \%$, AO: $6.6 \pm$ $1.1 \%, t=7.36, \mathrm{p}<0.01)$.
Assuming enrichments of $\sim 1 \%{ }^{13} \mathrm{C}$ and $3.4 \%{ }^{15} \mathrm{~N}$ per trophic level (De Niro \& Epstein 1978, 1981) the $\delta^{13} \mathrm{C}$ and $\delta^{15} \mathrm{~N}$ annual means for a fin whale feeding on krill in the MS or in the AO would be $-18.3 \pm$ $0.5 \% ; 7.8 \pm 0.6 \%$ and $-20.2 \pm 0.3 \%$; $10 \pm 1.1 \%$, respectively.

\section{Stable isotopes of fin whale baleen plates}

The isotopic variations in the 10 baleen plates, representing 190 pairs of $\delta^{13} \mathrm{C}$ to $\delta^{15} \mathrm{~N}$ analyses and C:N ratios along the L-axis of the baleen plates are reported in Table 4. The mean and SD of all $190 \mathrm{C:N}$ ratios for all BPs across all baleen lengths is $3.4 \pm 0.1$ (Table 4), which is in agreement with the theoretical $\mathrm{C}: \mathrm{N}$ atomic ratio of keratin $\left(\mathrm{O}^{\prime}\right.$ Connell \& Hedges 1999).

Among all 190 baleen samples and across all lengths, $\delta^{13} \mathrm{C}$ and $\delta^{15} \mathrm{~N}$ values ranged between -19.3 and $-17 \%$, and 6.3 and $10.0 \%$, respectively (Table 1 ). The $\delta^{13} \mathrm{C}$ ranges (max. $\delta^{13} \mathrm{C}$ to $\min . \delta^{13} \mathrm{C}$ along a baleen plate) are rather small for most BPs $(<1.1 \%$; Table 1), except for BP8 and BP10 (1.3 and 1.9\%, respectively). BPs 3,9 , and 10 show the highest $\delta^{15} \mathrm{~N}$ range values $(1.6,1.5$, and $2.2 \%$, respectively; Table 1). Both BP1 and BP2 showed a higher $\delta^{15} \mathrm{~N}$ mean $(9.4 \pm 0.2 \%$ and $8.1 \pm 0.2 \%$, respectively) than the other BPs (6.8 to $7.7 \%$; p always $<0.05$ and even $<0.001$ for most of the BPs, $\mathrm{W}=0$ ).

Considering the records along the plate, positive or negative trends in $\delta^{13} \mathrm{C}$ and $\delta^{15} \mathrm{~N}$ with respect to the distance from the top of the plates $(\mathrm{W}=0)$ were found (Figs. 2 \& 3). The relationships between $\delta^{13} \mathrm{C}$ along the L-axis were only significant for BP5 and BP9, which both exhibit significant slopes $(\mathrm{p}<0.05)$.

While $\delta^{13} \mathrm{C}$ of BP3 (lateral position) and BP4 (frontal area) were sampled from the same fin whale, no relationship was found ( $p=0.92$; Fig. 2). BP4 was half the size of BP3 and probably represents a shorter timespan. Mean BP4 $\delta^{13} \mathrm{C}$ record $(-18.1 \pm 0.4 \%)$ is very similar to that found for BP3 between 0 and $15.7 \mathrm{~cm}$ $(-18.3 \pm 0.2 \%)(p>0.05) \cdot \delta^{13} \mathrm{C}$ of $\mathrm{BP} 3$ showed $\mathrm{a}$ change at $\sim 17.6$ to $20.5 \mathrm{~cm}$ (mean $\pm \mathrm{SD}=-17.8 \pm$ $0.3 \%$ ). The same results were observed regarding $\delta^{15} \mathrm{~N}$ with relatively similar mean values for BP4 $(7.7 \pm 0.3 \%$ ) and BP3 (between 0 and $15.7 \mathrm{~cm}=7.4 \pm$ $0.3 \%, \mathrm{p}>0.05)$. The mean $\delta^{15} \mathrm{~N}$ values of BP3 between 17.6 and $20.5 \mathrm{~cm}(6.7 \pm 0.3 \%)$ are significantly lower than the values observed between 0 to $15.7 \mathrm{~cm}(\mathrm{p}<0.05)$ and 21.4 to $32.2 \mathrm{~cm}(\mathrm{p}<0.05)$. Significant covariation between $\delta^{13} \mathrm{C}$ and $\delta^{15} \mathrm{~N}$ was also found in BP3 $\left(\mathrm{r}^{2}=0.33\right)$; slope $\left.=-0.45, \mathrm{p}<0.001\right)$. 
Table 4. Balaenoptera physalus. Carbon (C) and nitrogen (N) stable isotope and C:N ratios measured along fin whale baleen plate length (L-axis, see Fig. 1) by plate reference number (collection year). All samples were measured along W $=0$ axis except for BP6, which was measured as $\mathrm{W}=2 \mathrm{~cm}$. nd: lost sample

\begin{tabular}{|c|c|c|c|c|c|c|c|c|c|c|c|}
\hline $\begin{array}{l}\text { Reference number } \\
\text { (collection year) }\end{array}$ & $\begin{array}{l}\text { L-axis } \\
(\mathrm{cm})\end{array}$ & $\begin{array}{l}\text { W-axis } \\
(\mathrm{cm})\end{array}$ & $\begin{array}{l}\delta^{13} \mathrm{C} \\
(\% \circ)\end{array}$ & $\begin{array}{l}\delta^{15} \mathrm{~N} \\
(\%)\end{array}$ & $C: N$ & $\begin{array}{l}\text { Reference number } \\
\text { (collection year) }\end{array}$ & $\begin{array}{l}\text { L-axis } \\
(\mathrm{cm})\end{array}$ & $\begin{array}{l}\text { W-axis } \\
(\mathrm{cm})\end{array}$ & $\begin{array}{l}\delta^{13} \mathrm{C} \\
(\% \circ)\end{array}$ & $\begin{array}{l}\delta^{15} \mathrm{~N} \\
(\% \circ)\end{array}$ & $C: N$ \\
\hline \multirow[t]{17}{*}{ BP1(1975) } & 4 & 0 & -17.84 & 8.90 & 3.4 & \multirow[t]{9}{*}{ BP4 (1989) } & 1.7 & 0 & -17.54 & 7.44 & 3.4 \\
\hline & 5.7 & 0 & -17.95 & 9.36 & 3.4 & & 3.8 & 0 & -17.99 & 7.54 & 3.4 \\
\hline & 7.3 & 0 & -17.98 & 9.30 & 3.4 & & 4.7 & 0 & -18.12 & 8.34 & 3.4 \\
\hline & 9.1 & 0 & -18.55 & 9.21 & 3.5 & & 6.4 & 0 & -18.62 & 7.92 & 3.4 \\
\hline & 10.5 & 0 & -18.49 & 9.61 & 3.4 & & 7.4 & 0 & -18.53 & 7.46 & 3.4 \\
\hline & 12 & 0 & -18.18 & 9.95 & 3.4 & & 9.3 & 0 & -18.44 & 7.59 & 3.4 \\
\hline & 13.7 & 0 & -18.13 & 9.61 & 3.4 & & 10.4 & 0 & nd & 7.78 & nd \\
\hline & 15.2 & 0 & -17.99 & 9.53 & 3.5 & & 12.4 & 0 & -17.65 & 7.70 & 3.4 \\
\hline & 16.7 & 0 & -17.87 & 9.47 & 3.5 & & 13.3 & 0 & -17.78 & 7.61 & 3.3 \\
\hline & 18.2 & 0 & -17.87 & 9.51 & 3.5 & \multirow[t]{10}{*}{ BP5 (1990) } & 0.65 & 0 & -18.11 & 7.64 & 3.4 \\
\hline & 19.7 & 0 & -17.92 & 9.40 & 3.4 & & 1.75 & 0 & -17.91 & 7.33 & 3.3 \\
\hline & 21.2 & 0 & -18.07 & 9.22 & 3.5 & & 2.85 & 0 & -18.25 & 7.27 & 3.3 \\
\hline & 22.7 & 0 & -18.04 & 9.15 & 3.4 & & 3.90 & 0 & -18.45 & 7.09 & 3.4 \\
\hline & 24.2 & 0 & -18.12 & 9.36 & 3.5 & & 5.10 & 0 & -18.19 & 6.69 & 3.3 \\
\hline & 25.6 & 0 & -17.75 & 9.75 & 3.5 & & 6.20 & 0 & -18.24 & 7.15 & 3.3 \\
\hline & 29 & 0 & -18.03 & 9.38 & nd & & 7.25 & 0 & -18.75 & 7.11 & 3.4 \\
\hline & 30.7 & 0 & -17.87 & 9.60 & 3.5 & & 8.30 & 0 & -18.56 & 7.31 & 3.3 \\
\hline \multirow[t]{7}{*}{ BP2 (1980) } & 7.1 & 0 & -17.41 & 8.16 & 3.6 & & 9.40 & 0 & -18.51 & 7.56 & 3.3 \\
\hline & 12.2 & 0 & -17.97 & 7.99 & 3.5 & & 10.40 & 0 & -18.30 & 7.25 & 3.3 \\
\hline & 16.7 & 0 & -17.74 & 8.26 & 3.5 & \multirow[t]{17}{*}{ BP6 (1992) } & 0 & 2 & -17.98 & 6.71 & 3.7 \\
\hline & 21.3 & 0 & -16.98 & 7.99 & 3.5 & & 2 & 2 & -18.36 & 7.48 & 3.5 \\
\hline & 26.8 & 0 & -17.16 & 8.20 & 3.5 & & 3.8 & 2 & -18.72 & 7.38 & 3.6 \\
\hline & 31.1 & 0 & -17.61 & 8.35 & 3.5 & & 5.8 & 2 & -17.98 & 6.82 & 3.6 \\
\hline & 36.4 & 0 & -17.09 & 7.86 & 3.5 & & 7.8 & 2 & -18.48 & 7.96 & 3.4 \\
\hline \multirow[t]{30}{*}{ BP3 (1989) } & 0 & 0 & -18.15 & 7.62 & 3.4 & & 9.8 & 2 & -18.47 & 7.60 & 3.4 \\
\hline & 0.8 & 0 & -18.05 & 7.60 & 3.4 & & 12 & 2 & -18.29 & 7.47 & 3.7 \\
\hline & 1.5 & 0 & -18.45 & 7.03 & $\begin{array}{l}3.4 \\
3.4\end{array}$ & & 16.2 & 2 & -18.40 & 7.75 & 3.4 \\
\hline & 2.4 & 0 & -18.12 & 6.72 & 3.4 & & 18.3 & 2 & -17.76 & 7.39 & 3.6 \\
\hline & 3.3 & 0 & -17.85 & 7.35 & $\begin{array}{l}3.4 \\
3.4\end{array}$ & & 20.2 & 2 & -18.52 & 7.80 & 3.4 \\
\hline & 4.3 & 0 & -18.35 & 7.93 & 3.4 & & 22.2 & 2 & -18.54 & 7.84 & 3.4 \\
\hline & 6.3 & 0 & -18.24 & 7.77 & 3.4 & & 23.9 & 2 & -17.91 & 6.68 & 3.6 \\
\hline & 7.2 & 0 & -18.38 & 7.70 & $\begin{array}{l}3.4 \\
3.4\end{array}$ & & 25.8 & 2 & -18.33 & 7.39 & 3.4 \\
\hline & 8.9 & 0 & -18.37 & 7.28 & $\begin{array}{l}3.4 \\
3.4\end{array}$ & & 27.7 & 2 & -18.14 & 7.90 & 3.4 \\
\hline & 9.9 & 0 & $\begin{array}{l}-10.07 \\
-18.35\end{array}$ & $\begin{array}{l}T .20 \\
7.31\end{array}$ & $\begin{array}{l}3.4 \\
3.4\end{array}$ & & 29.8 & 2 & -17.84 & 7.36 & 3.7 \\
\hline & 11.7 & 0 & -18.36 & 7.73 & $\begin{array}{l}3.4 \\
3.4\end{array}$ & & 31.6 & 2 & -18.68 & 7.86 & 3.6 \\
\hline & 14.8 & 0 & -18.53 & 7.47 & $\begin{array}{l}3.4 \\
3.5\end{array}$ & & 33.8 & 2 & -18.23 & 8.06 & 3.4 \\
\hline & 15.7 & 0 & -18.18 & 7.21 & 3.4 & \multirow[t]{12}{*}{ BP7 (1993) } & 5.2 & 0 & -18.37 & 7.38 & 3.4 \\
\hline & 17.6 & 0 & -18.12 & 7.14 & 3.4 & & 6.9 & 0 & -18.71 & 7.45 & 3.4 \\
\hline & 18.5 & 0 & -17.69 & 6.63 & 3.4 & & 10.5 & 0 & -18.45 & 8.18 & 3.4 \\
\hline & 19.5 & 0 & -17.54 & 6.36 & 3.4 & & 11.7 & 0 & -18.42 & 7.71 & 3.4 \\
\hline & 20.5 & 0 & -17.67 & 6.70 & 3.4 & & 14.8 & 0 & -18.27 & 7.74 & 3.5 \\
\hline & 21.4 & 0 & -17.89 & 7.27 & 3.3 & & 16.5 & 0 & -18.28 & 7.96 & 3.5 \\
\hline & 22.4 & 0 & -17.82 & 6.86 & 3.4 & & 20.1 & 0 & -18.20 & 7.93 & 3.4 \\
\hline & 23.3 & 0 & -17.96 & 7.08 & 3.4 & & 21.6 & 0 & -18.29 & 7.95 & 3.4 \\
\hline & 24.5 & 0 & -18.10 & 6.65 & 3.3 & & 26.2 & 0 & -18.24 & 7.46 & 3.4 \\
\hline & 25.4 & 0 & -17.79 & 7.28 & 3.4 & & 28.4 & 0 & -18.32 & 7.77 & 3.4 \\
\hline & 26.4 & 0 & -17.72 & 7.23 & 3.4 & & 30 & 0 & nd & 7.74 & nd \\
\hline & 27.8 & 0 & -17.95 & 7.49 & 3.4 & & 34 & 0 & -18.09 & 6.84 & 3.3 \\
\hline & 28.2 & 0 & -17.98 & 7.06 & 3.4 & \multirow[t]{6}{*}{ BP8 (1996) } & 4 & 0 & -18.41 & 6.87 & 3.5 \\
\hline & 29 & 0 & -17.64 & 7.15 & 3.4 & & 5.4 & 0 & -18.90 & 6.69 & 3.7 \\
\hline & 29.9 & 0 & -17.62 & 7.10 & 3.4 & & 5.8 & 0 & -18.28 & 7.08 & 3.5 \\
\hline & 30.8 & 0 & -17.71 & 7.01 & 3.4 & & 6.2 & 0 & -19.32 & 6.69 & 3.9 \\
\hline & 31.6 & 0 & -17.83 & 7.10 & 3.4 & & 6.9 & 0 & -18.78 & 6.96 & 3.5 \\
\hline & 32.2 & 0 & -17.57 & 7.02 & 3.3 & & 8.3 & 0 & -18.82 & 6.74 & 3.6 \\
\hline
\end{tabular}


Table 4. (continued)

\begin{tabular}{|c|c|c|c|c|c|c|c|c|c|c|c|}
\hline $\begin{array}{l}\text { Reference number } \\
\text { (collection year) }\end{array}$ & $\begin{array}{l}\text { L-axis } \\
(\mathrm{cm})\end{array}$ & $\begin{array}{c}\text { W-axis } \\
(\mathrm{cm})\end{array}$ & $\begin{array}{l}\delta^{13} \mathrm{C} \\
(\% \circ)\end{array}$ & $\begin{array}{l}\delta^{15} \mathrm{~N} \\
(\%)\end{array}$ & $\mathrm{C}: \mathrm{N}$ & $\begin{array}{l}\text { Reference number } \\
\text { (collection year) }\end{array}$ & $\begin{array}{r}\text {-axis } \\
(\mathrm{cm})\end{array}$ & $\begin{array}{c}\text { W-axis } \\
(\mathrm{cm})\end{array}$ & $\begin{array}{c}\delta^{13} \mathrm{C} \\
(\% \circ)\end{array}$ & $\begin{array}{l}\delta^{15} \mathrm{~N} \\
(\% \circ)\end{array}$ & $C: N$ \\
\hline \multirow[t]{26}{*}{ BP (1996) } & 9.1 & 0 & -19.25 & 6.70 & 4.0 & \multirow{42}{*}{$\begin{array}{l}\text { BP10 (2002) } \\
\text { (continued) }\end{array}$} & 6.2 & 0 & -18.33 & 7.14 & 3.4 \\
\hline & 9.7 & 0 & -18.76 & 6.57 & 3.7 & & 7.25 & 0 & -18.83 & 7.31 & 3.8 \\
\hline & 10.5 & 0 & -18.78 & 6.44 & 3.6 & & 8.15 & 0 & -18.46 & 7.15 & 3.3 \\
\hline & 11.2 & 0 & -18.66 & 6.58 & 3.6 & & 9.25 & 0 & -18.70 & 7.56 & 3.4 \\
\hline & 12 & 0 & -18.02 & 6.79 & 3.4 & & 10.35 & 0 & -18.41 & 7.68 & 3.4 \\
\hline & 12.7 & 0 & -18.23 & 6.93 & 3.5 & & 10.35 & 0 & -18.34 & 7.96 & 3.4 \\
\hline & 13.5 & 0 & -18.05 & 6.61 & 3.6 & & 11.45 & 0 & -18.24 & 7.95 & 3.4 \\
\hline & 15.5 & 0 & -18.20 & 6.79 & 3.6 & & 12.55 & 0 & -18.16 & 7.90 & $\begin{array}{l}3.4 \\
3.3\end{array}$ \\
\hline & 16.4 & 0 & -18.05 & 7.01 & 3.5 & & 13 & 0 & -18.66 & 8.38 & $\begin{array}{l}0.0 \\
3.6\end{array}$ \\
\hline & 17.2 & 0 & -17.97 & 7.07 & 3.6 & & & 0 & -18.12 & $\begin{array}{l}0.00 \\
8.35\end{array}$ & $\begin{array}{l}3.0 \\
3.3\end{array}$ \\
\hline & 18.1 & 0 & -18.64 & 6.77 & 3.7 & & $\begin{array}{l}14.75 \\
16\end{array}$ & & & 8.35 & 3.3 \\
\hline & 18.9 & 0 & -18.26 & 7.03 & 3.6 & & 16 & 0 & -18.11 & 8.00 & 3.4 \\
\hline & 19.7 & 0 & -18.62 & 7.00 & 3.7 & & 17.2 & 0 & -18.69 & 8.49 & 3.5 \\
\hline & 20.5 & 0 & -18.21 & 7.04 & 3.6 & & 18.35 & 0 & -18.50 & 8.68 & 3.3 \\
\hline & 22.4 & 0 & -18.46 & 6.32 & 3.5 & & 19.5 & 0 & -18.53 & 8.23 & 3.3 \\
\hline & 23.4 & 0 & -18.29 & 6.64 & 3.5 & & 20.65 & 0 & -18.84 & 7.17 & 3.4 \\
\hline & 24.4 & 0 & -18.73 & 7.02 & 3.6 & & 21.75 & 0 & -18.94 & 6.50 & 3.4 \\
\hline & 25.4 & 0 & -18.28 & 6.66 & 3.5 & & 23.25 & 0 & -18.83 & 8.14 & 3.4 \\
\hline & 26.2 & 0 & -18.80 & 7.23 & 3.7 & & 24.55 & 0 & -19.25 & 7.95 & 3.5 \\
\hline & 27.1 & 0 & -18.39 & 6.99 & 3.5 & & 27.15 & 0 & -18.26 & 7.82 & 3.4 \\
\hline & 28.2 & 0 & -18.52 & 6.93 & 3.6 & & 28.55 & 0 & -18.05 & 8.09 & 3.4 \\
\hline & 29.5 & 0 & -18.36 & 6.69 & 3.6 & & $\begin{array}{l}20.05 \\
29.65\end{array}$ & 0 & $\begin{array}{l}-10.00 \\
-17.94\end{array}$ & $\begin{array}{l}0.09 \\
7.23\end{array}$ & $\begin{array}{l}0.4 \\
3.3\end{array}$ \\
\hline & 30.6 & 0 & -17.99 & 6.97 & 3.5 & & $\begin{array}{l}29.05 \\
30.9\end{array}$ & 0 & $\begin{array}{l}-17.94 \\
-18.14\end{array}$ & $\begin{array}{l}f .23 \\
7.46\end{array}$ & $\begin{array}{l}3.3 \\
3.3\end{array}$ \\
\hline & 31.8 & 0 & -18.14 & 6.69 & 3.5 & & 30.9 & 0 & -18.14 & $\begin{array}{l}t .46 \\
7.92\end{array}$ & 3.3 \\
\hline & 32.9 & 0 & -18.30 & 6.88 & 3.5 & & 32.1 & 0 & -18.50 & 7.92 & 3.5 \\
\hline & 33.9 & 0 & -18.08 & 7.16 & 3.5 & & 33.2 & 0 & -18.34 & 7.97 & 3.4 \\
\hline \multirow{12}{*}{ BP9 (2000) } & 0.35 & 0 & -17.57 & 7.29 & 3.5 & & 34.3 & 0 & -18.15 & 7.87 & 3.4 \\
\hline & 1.25 & 0 & -18.05 & 6.84 & 3.4 & & 35.5 & 0 & -18.08 & 7.60 & 3.5 \\
\hline & 2.15 & 0 & -17.53 & $\begin{array}{l}0.04 \\
7.16\end{array}$ & $\begin{array}{l}3.4 \\
3.4\end{array}$ & & 36.7 & 0 & -18.19 & 7.29 & 3.5 \\
\hline & $\begin{array}{l}2.10 \\
3\end{array}$ & 0 & -17.79 & 7.11 & $\begin{array}{l}3.4 \\
3.4\end{array}$ & & 37.9 & 0 & -18.24 & 7.31 & 3.4 \\
\hline & 3.85 & 0 & -18.02 & $\begin{array}{l}T .11 \\
7.83\end{array}$ & $\begin{array}{l}3.4 \\
3.4\end{array}$ & & 39 & 0 & -18.29 & 7.34 & 3.4 \\
\hline & 4.75 & 0 & -18.16 & 7.55 & $\begin{array}{l}3.4 \\
3.4\end{array}$ & & 40.2 & 0 & -17.95 & 7.23 & 3.4 \\
\hline & 5.8 & 0 & -17.86 & 6.58 & $\begin{array}{l}3.4 \\
3.4\end{array}$ & & 42.4 & 0 & -18.10 & 7.38 & 3.3 \\
\hline & 6.85 & 0 & -18.18 & 6.40 & 3.4 & & 43.4 & 0 & -19.21 & 7.08 & 3.7 \\
\hline & 7.25 & 0 & -18.32 & 6.36 & 3.3 & & 44.5 & 0 & -17.79 & 7.64 & 3.3 \\
\hline & 8.05 & 0 & -17.90 & 7.10 & 3.4 & & 45.6 & 0 & -18.07 & 7.36 & 3.3 \\
\hline & 8.7 & 0 & -18.18 & 7.09 & 3.3 & & 46.5 & 0 & -17.88 & 8.10 & 3.3 \\
\hline & 9.7 & 0 & -18.06 & 6.83 & 3.4 & & 47.5 & 0 & -17.95 & 7.83 & 3.3 \\
\hline \multirow[t]{4}{*}{ BP10 (2002) } & 0.9 & 0 & -18.02 & 7.61 & 3.3 & & 48.5 & 0 & -18.50 & 7.81 & 3.5 \\
\hline & 3 & 0 & -18.15 & 8.12 & 3.4 & & 49.55 & 0 & -17.73 & 7.47 & 3.3 \\
\hline & 4.1 & 0 & -18.08 & 8.08 & 3.4 & & 50.65 & 0 & -17.37 & 7.91 & 3.3 \\
\hline & 5.1 & 0 & -18.19 & 7.73 & 3.3 & & 51.55 & 0 & -17.75 & 7.25 & 3.3 \\
\hline
\end{tabular}

\section{Stable isotopes signature of krill and fin whale baleen, and trophic level of fin whales}

The mean level of $\delta^{15} \mathrm{~N}$ signature of baleen plates $(7.6 \pm 0.7 \%)$ was 3.2 and $1.0 \%$ higher than that of bulk (non-lipid-extracted) Meganyctiphanes norvegica sampled in the Mediterranean Sea or in the Atlantic Ocean, respectively. The mean level of $\delta^{13} \mathrm{C}$ signature of baleen plates $(-18.2 \pm 0.4 \%$ ) was $1.1 \%$ and $3.0 \%$ higher than that of annual mean bulk krill sampled in the Mediterranean Sea or in the Atlantic Ocean, respectively (Tables $2 \& 3$ ).
According to the methods described by De Niro \& Epstein $(1978,1981)$ we corrected the $\delta^{13} \mathrm{C}$ and $\delta^{15} \mathrm{~N}$ values of the Mediterranean Sea and the Atlantic Ocean krill by 1.0 and $3.4 \%$, respectively to take into account the trophic level enrichment factor for carbon and nitrogen. When compared to the corrected spring and fall $\delta^{13} \mathrm{C}$ and $\delta^{15} \mathrm{~N}$ values of the bulk Mediterranean and to the corrected annual $\delta^{13} \mathrm{C}$ and $\delta^{15} \mathrm{~N}$ values of the bulk Atlantic krill samples, the $\delta^{13} \mathrm{C}$ and $\delta^{15} \mathrm{~N}$ values of the 10 BPs are more closely related to the annualized Mediterranean krill values (Fig. 4A). All but one (BP2) $\delta^{13} \mathrm{C}$ mean value fell 

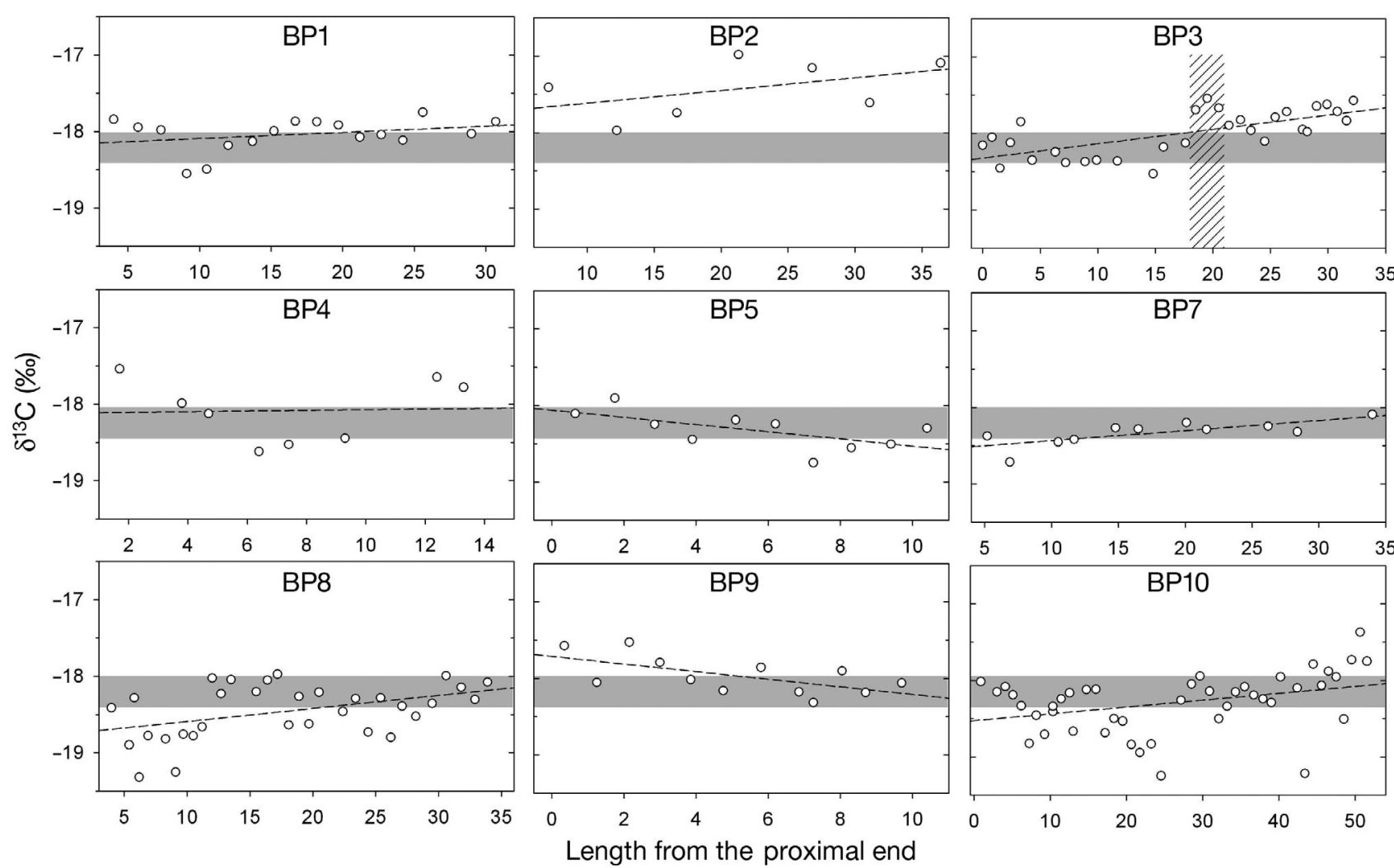

Fig. 2. Balaenoptera physalus. Intra-individual stable carbon isotope values (expressed per ml) along the length of baleen plates of fin whales stranded at western Mediterranean coasts between 1975 and 2002. All plots represent W = 0 sampled whales. Grey areas represent the range of values comprising $>50 \%$ of the isotopic ratios of the whole dataset. The dashed vertical band in Panel BP3 suggests the weaning period. BP3 \& BP4 were from the same individual but sampled at lateral and frontal sides of the jaw. BP6 is not included because it was sampled at $\mathrm{W}=2 \mathrm{~cm}$

within the reference range corresponding to the outer-limits of the $\pm 1 \mathrm{SD}$ range of spring and fall values combined of the $\delta^{13} \mathrm{C}_{\text {corrected }}$ values of the Mediterranean sea krill (-18.9 to $-17.5 \%)$.

When excluding BP2, which is well outside the range of $\delta^{13} \mathrm{C}_{\text {corrected }}$ krill values, all but BP8 are centered on the $\pm \mathrm{SD}$ range of the Mediterranean spring krill mean value, and all but BP9 have few consistent values with fall Mediterranean krill $\delta^{13} \mathrm{C}$. Fig. 4B shows that some individuals have $\delta^{13} \mathrm{C}$ values isotopic values exceeding the range expected from the spring and fall Mediterranean krill $\delta^{13} \mathrm{C}$ values. However, even the most depleted values $(-18.9$ to $-19.3 \%$ ) of the BPs 8 and 10 plates samples were not consistent with the $\delta^{13} \mathrm{C}_{\text {corrected }}$ signature of krill sampled in the Atlantic Ocean (-20.6 to $-19.1 \%$ ).

Most $\delta^{15} \mathrm{~N}$ plate values are also consistent with spring Mediterranean krill $\delta^{15} \mathrm{~N}$ mean value (Fig. 4A). The main exception being the BP1 with a $\delta^{15} \mathrm{~N}$ exceeding the $\delta^{15} \mathrm{~N}$ signature expected from the fall and spring Mediterranean krill isotopic signature. BP2 has intermediate $\delta^{15} \mathrm{~N}$ values between fall and spring Mediterranean krill $\delta^{15} \mathrm{~N}$. BPs 4 and 10 are the only plates showing consistent $\delta^{15} \mathrm{~N}$ values with both fall and spring Mediterranean krill $\delta^{15} \mathrm{~N}$ mean value. All plates except BPs 1, 2, and 4 are characterized by $\delta^{15} \mathrm{~N}$ values lower than expected from the spring and fall Mediterranean krill $\delta^{15} \mathrm{~N}$ signatures (Fig. 4C).

Assuming that the euphausid is a primary consumer (i.e. mostly herbivorous and omnivorous), a trophic level of 2 can be assigned to this species (e.g. Vander Zanden \& Rasmussen 2001). Using mean values for the whales and their euphausid prey in the formula proposed by Vander Zanden and Rasmussen (2001) for the trophic level value (TL):

$\mathrm{TL}=2+\left(\delta^{15} \mathrm{~N}_{\text {baleen }}-\delta^{15} \mathrm{~N}_{\text {uncorrected M. norvegica }}\right) / 3.4$

we calculate a TL of $2.9 \pm 0.3($ mean $\pm \mathrm{SD}$ ) for fin whales based on the annual mean $\delta^{15} \mathrm{~N}$ Mediterranean euphausids. The TL varies between 2.8 in fall and 3.0 in spring due to the effect of the seasonal $\delta^{15} \mathrm{~N}$ variability observed in the euphausids. Using the Atlantic euphausids $\delta^{15} \mathrm{~N}$ values, a mean TL of $2.3 \pm 0.4$ (2.0 in fall and 2.5 for spring) can be esti- 

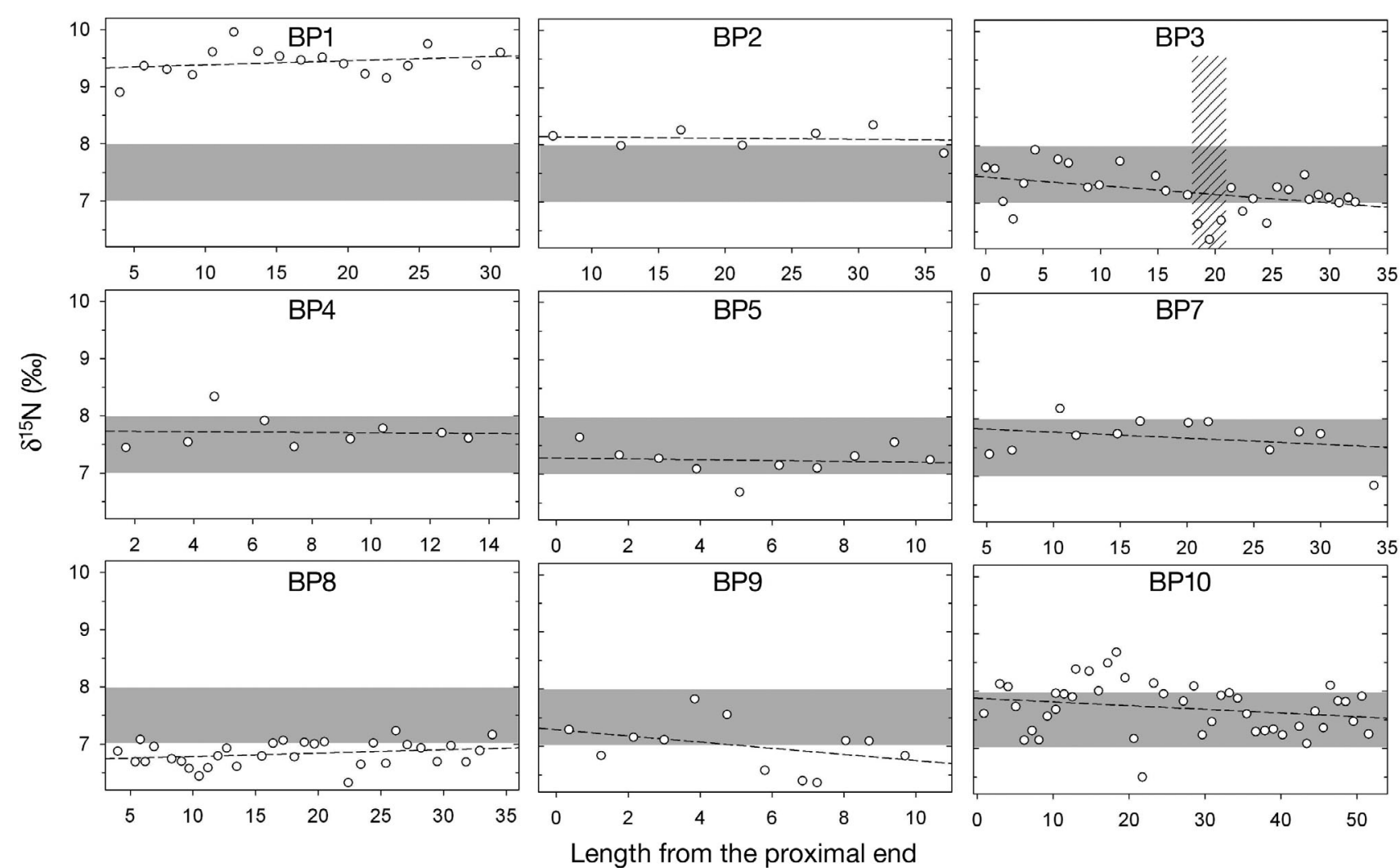

Fig. 3. Balaenoptera physalus. Intra-individual stable nitrogen isotope values (expressed per ml) along the length of baleen plates of fin whales stranded at western Mediterranean coasts between 1975 and 2002. For details see legend of Fig. 2

mated. The $\mathrm{TL}=2.9 \pm 0.3$ calculated with the Mediterranean $\delta^{15} \mathrm{~N}_{\text {uncorrected M. norvegica }}$ value is closer to the $\mathrm{TL}=3.2$ estimated from the dietary analysis of Mediterranean fin whale by Kaschner et al. (2004).

\section{Decadal trends in stable isotope signature}

The evolution of the keratin $\delta^{13} \mathrm{C}$ and $\delta^{15} \mathrm{~N}$ from the $10 \mathrm{BPs}$ of fin whales stranded along the Western Mediterranean coasts over a $27 \mathrm{yr}$ span is presented in Fig. $5 \mathrm{~A}, \mathrm{~B} . \delta^{13} \mathrm{C}$ and $\delta^{15} \mathrm{~N}$ mean values show important changes between 1975 and 2002. Whereas $\delta^{15} \mathrm{~N}$ variances statistically significantly increase with time, the slight positive increase in $\delta^{13} \mathrm{C}$ variances is not statistically significant $(\mathrm{p}>0.68)$ from linear regression. We calculated the regression equation using the mean values of all BPs (Table 1). The linear fit shows a strong correlation between $\delta^{15} \mathrm{~N}$ means and years of collection $\left(r^{2}=0.58, n=10, p=0.01\right)$ and a smaller one for $\delta^{13} \mathrm{C}\left(\mathrm{r}^{2}=0.29, \mathrm{n}=10\right)$. A polynomial fit (third order) applied to both $\delta^{13} \mathrm{C}$ and $\delta^{15} \mathrm{~N}$ means increased the correlation between stable isotope evolution and years. The $\delta^{13} \mathrm{C}$ versus year fit shows a sinusoidal curve and an isotopic shift in 1980 (Fig. 5A). The $\delta^{15} \mathrm{~N}$ versus year 'abruptly' decreases between 1975 and 1980 but shows less variation between 1990 and 2002 (Fig. 5B).

\section{Satellite tracking}

Eleven fin whales were tagged with satellite-monitored radio transmitters off the Provençal coast from 1 August to 20 August 2003. Argos positions were obtained from 8 individuals over the course of 9 mo (Table 5). Seven individuals remained in the northwestern part of the Mediterranean Sea through fall and winter, and 1 individual (tag 10842) moved into the Atlantic Ocean (Fig. 6).

\section{DISCUSSION}

Satellite telemetry provides evidence, that some fin whales migrate from the Mediterranean Sea to the Atlantic Ocean; however, most individuals remain within the western basin during fall and winter. 


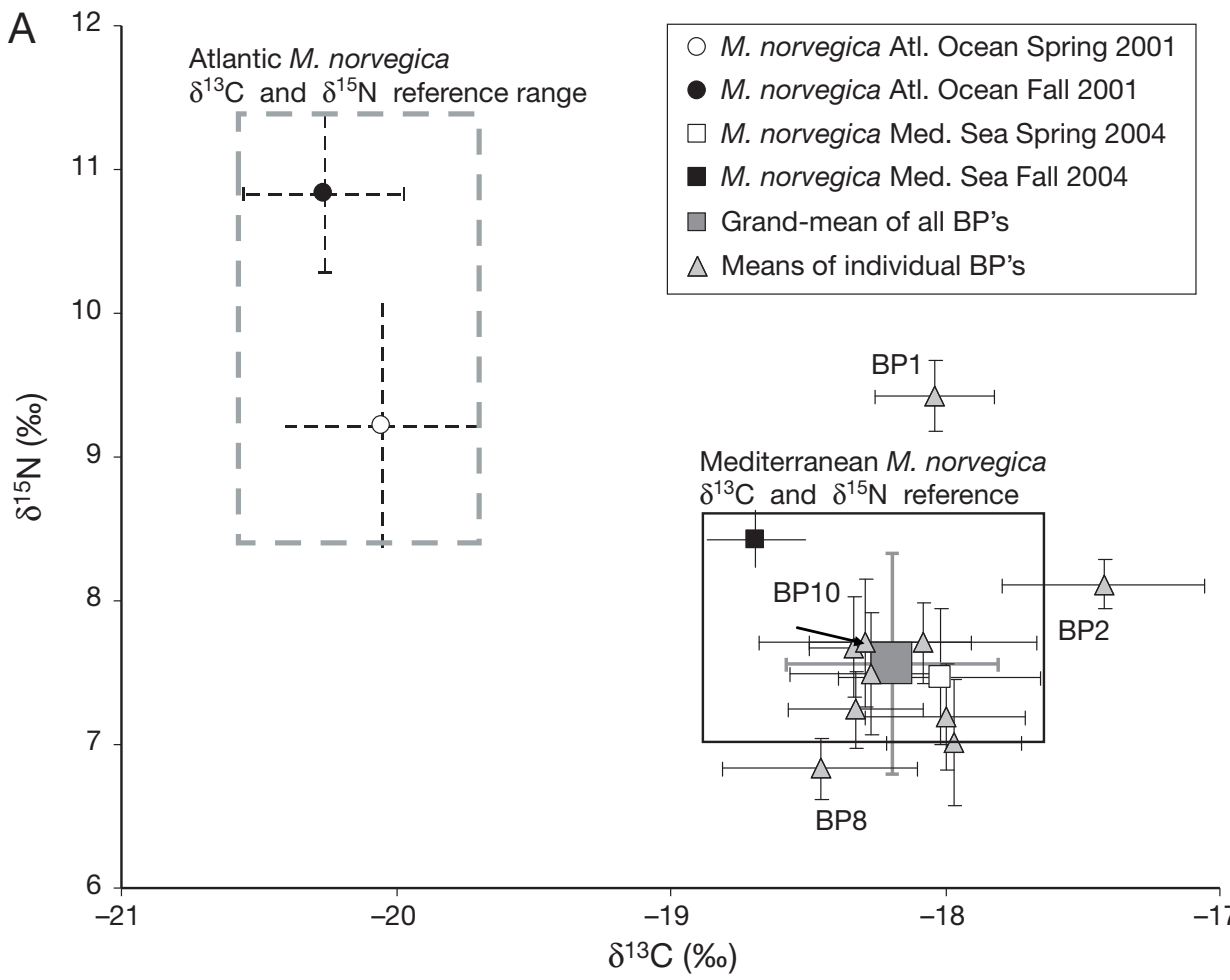

Fig. 4. Meganyctiphanes norvegica and Balaenoptera physalus. (A) Nitrogen and carbon stable isotope ratios of the 10 baleen plates of stranded fin whales $(\square)$ and of each individual $(\triangle)$ compared with $M$. norvegica (krill) $\delta^{13} \mathrm{C}$ and $\delta^{15} \mathrm{~N}$ values from the Mediterranean Sea ( $\square$ : spring; 口: fall) and Atlantic Ocean (O: spring; O: fall). $\delta^{13} \mathrm{C}$ and $\delta^{15} \mathrm{~N}$ krill data represent trophic enrichment corrected values (1 and $3.4 \%$, respectively) and non-lipid-extracted values. The boxes represent the Atlantic Ocean (- - ) and the Mediterranean Sea (-) krill reference ranges that correspond to the outer-limits of the $\pm 1 \mathrm{SD}$ range of spring and fall values combined of the $\delta^{13} \mathrm{C}_{\text {corrected val- }}$ ues of the krill. Intra-individual (B) $\delta^{13} \mathrm{C}$ and (C) $\delta^{15} \mathrm{~N}$ variations along the length of the plates
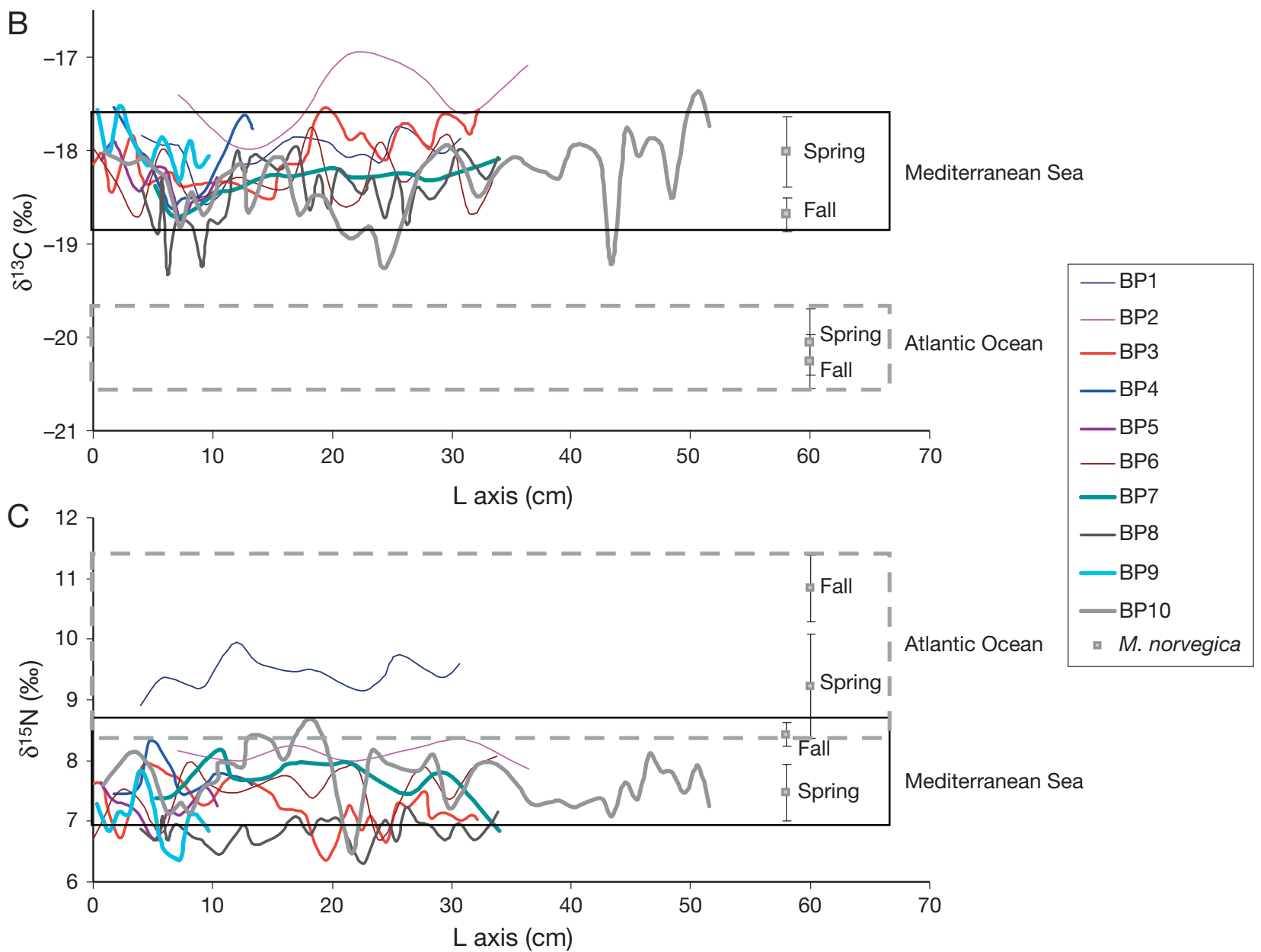

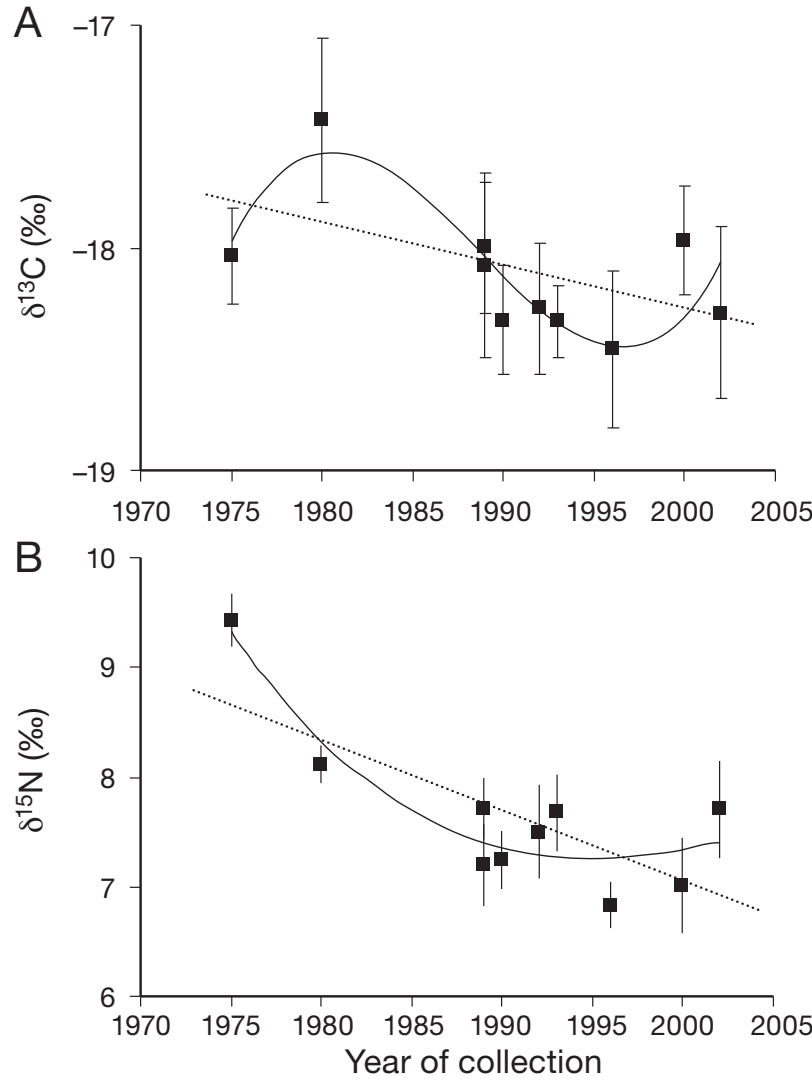

Fig. 5. Balaenoptera physalus. Variations of (A) $\delta^{13} \mathrm{C}$ and (B) $\delta^{15} \mathrm{~N}$ values of 10 fin whale baleen plates versus year of collection, means $\pm \mathrm{SD}$. The line curves fitting the data are linear $\left(\delta^{13} \mathrm{C}=-0.02 \times+20.14 ; \mathrm{r}^{2}=0.29 ; \delta^{15} \mathrm{~N}=-0.07 \times\right.$ Years $+142.5 ;$ $\left.\mathrm{r}^{2}=0.58\right)$ and cubic polynomial regressions $\left(\delta^{13} \mathrm{C}=0.0004 \times\right.$ Years $^{3}-2.6145 \times$ Years $^{2}+5199 \times$ Years $-3 \times 10^{6} ; \mathrm{r}^{2}=0.70 ;$ $\delta^{15} \mathrm{~N}=-8 \times 10^{-05} \times$ Years $^{3}+0.4886 \times$ Years $^{2}-981.82 \times$ Years + $\left.657624 ; r^{2}=0.84\right)$

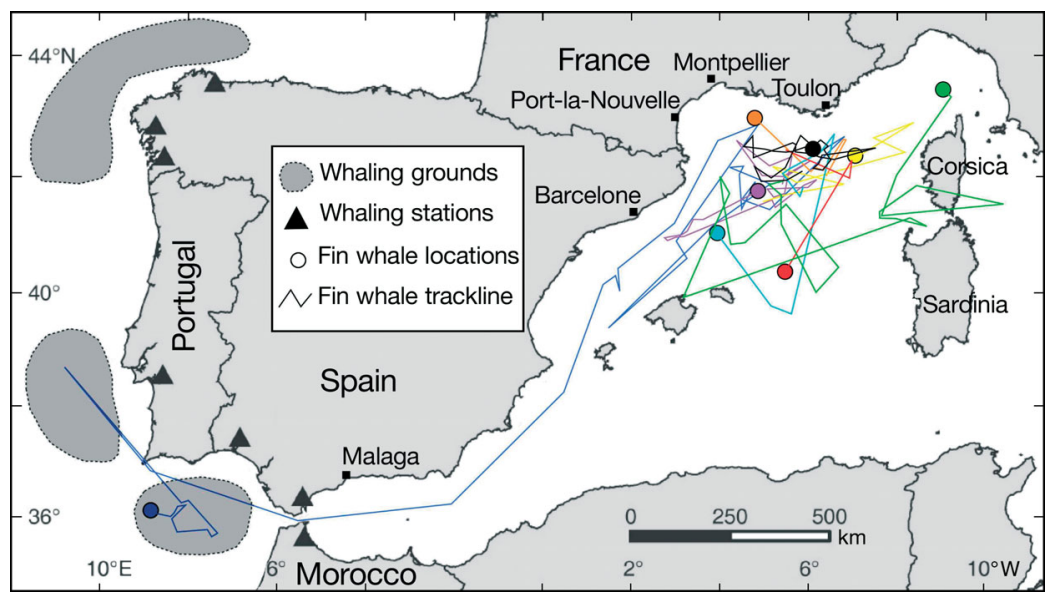

Fig. 6. Balaenoptera physalus. Argos locations of 7 individuals tagged with satellite-monitored radio transmitters off the Provençal coast from 1 August to 20 August 2003. Tags (see Table 5) : $\bigcirc=10838, \bigcirc=23029, \bullet=10838, \bigcirc=23032$, $\mathrm{O}=23042, \mathrm{O}=10836, \mathrm{O}=10842, \mathrm{O}=23041$. The tag 23032 is not shown, as only 2 locations were obtained from this individual over a $43.3 \mathrm{~d}$ period and within initial tagging area
Table 5. Balaenoptera physalus. Tag identification number (PTT), deployment dates, number of days following tagging with locations, duration of operation (message days), and minimum distances travelled by 8 fin whales tagged in the northwestern Mediterranean Sea during August 2003.

TAG 10842: individual moved into the Atlantic Ocean

\begin{tabular}{|lcccc|}
\hline PTT & $\begin{array}{c}\text { Date } \\
\text { deployed }\end{array}$ & $\begin{array}{c}\text { Location } \\
(\mathrm{d})\end{array}$ & $\begin{array}{c}\text { Message } \\
(\mathrm{d})\end{array}$ & $\begin{array}{c}\text { Distance } \\
(\mathrm{km})\end{array}$ \\
\hline 10836 & $8 / 12 / 03$ & 145.1 & 192.7 & 913 \\
10838 & $8 / 18 / 03$ & 278.0 & 296.0 & 4260 \\
10842 & $8 / 16 / 03$ & 138.6 & 138.6 & 4057 \\
23029 & $8 / 18 / 03$ & 45.1 & 57.6 & 1079 \\
23032 & $8 / 18 / 03$ & 43.3 & 44.3 & 405 \\
23033 & $8 / 4 / 03$ & 140.4 & 140.4 & 761 \\
23041 & $8 / 8 / 03$ & 175.3 & 228.8 & 419 \\
23042 & $8 / 16 / 03$ & 301.0 & 394.0 & 1461 \\
Averages & & 158.3 & 186.6 & 1669 \\
\hline
\end{tabular}

Therefore this population is exposed, year-round, to heavy shipping traffic, as the 3 largest Mediterranean ports - Barcelona, Marseille, and Genovaare contiguous to the main fin whale summer foraging grounds (Forcada et al. 1996, Monestiez et al. 2006, Cotté et al. 2009).

The stable isotope analyses of baleen plates reveal that most stranded fin whales in the northwestern Mediterranean Sea did not present $\delta^{13} \mathrm{C}$ oscillations. Assuming a $+3.4 \%$ trophic enrichment factor for $\delta^{15} \mathrm{~N}$ and $+1 \%$ for $\delta^{13} \mathrm{C}$, these results suggest year-round residency within the western Mediterranean Sea. Few $\delta^{13} \mathrm{C}$ values were either enriched (BP2) or depleted (BP8, BP10) compared to the $\delta^{13} \mathrm{C}$ Mediterranean krill reference range (Fig. 4B).

Both $\delta^{13} \mathrm{C}$ and $\delta^{15} \mathrm{~N}$ variations along the length of BP2 may be cyclical, suggesting that BP2 fin whale may regularly visit different foraging grounds, possibly by alternating between the northwestern Mediterranean basin (where this whale was ultimately killed in a ship collision) during spring-summer seasons (31 and $12 \mathrm{~cm}$; Fig. 4B) and unidentified waters (where it fed at the same high trophic level compared to the other fin whales) $(\sim 21 \mathrm{~cm})$. However, the high $\delta^{13} \mathrm{C}$ values of BP2 suggest that this whale was unlikely to forage in the Atlantic Ocean. $\delta^{13} \mathrm{C}$ of BP10 and to a lesser extent BP8, which were both sampled in the Malaga region, also exhibit 'cyclic' patterns (Fig. 4B). The high $\delta^{13} \mathrm{C}$ ranges mea- 
sured along the length of BP8 and BP10 (1.3 and $1.9 \%$, respectively) suggest a broader foraging area for these individuals than for the other ones (range: 0.6 to $1.1 \%$ ). However, their $\delta^{13} \mathrm{C}$ suggest that these individuals spent most of their time in the Mediterranean basin feeding alternatively on spring and fall resources and exhibited short shifts marked by significant $\delta^{13} \mathrm{C}$ depletion. These depleted $\delta^{13} \mathrm{C}$ values are intermediate between the Mediterranean and Atlantic krill $\delta^{13} \mathrm{C}$ values, suggesting possible short excursions in the Atlantic Ocean or the nearby Strait of Gibraltar. The less-depleted $\delta^{13} \mathrm{C}$ values observed in the baleen plates compared to the expected Atlantic Ocean $\delta^{13} \mathrm{C}$ values can be explained either by the fact that those excursions were not long enough to allow the plate to equilibrate with the Atlantic prey $\delta^{13} \mathrm{C}$ values or that the fin whales restricted their Atlantic excursions to the Atlantic side of the Strait of Gibraltar, an historical Spanish whaling ground in the 1920s and 1950s and consistent with the data provided by satellite tracking (Sanpera \& Aguilar 1992; Fig. 6). In this hypothesis, the 'Gibraltar-Atlantic' prey $\delta^{13} \mathrm{C}$ values would be intermediate between Mediterranean and Atlantic values. As fin whales display maternally directed site fidelity, we can question the effect of the past intensive whaling on the migration patterns of this population. In the absence of such intensive whaling we would expect much higher variations in stable isotope values with time in the baleen of these whales.

As only 2 (BP10, and, to a lesser extent, BP8) out of the 10 baleen plates exhibited such 'cyclic' patterns in $\delta^{13} \mathrm{C}$, this behavior does not seem to prevail in this fin whale population. Interestingly both fin whales from the Malaga area show indications of such migratory pattern, suggesting that fin whales encountered in this region may be in transit between the Mediterranean Sea and the Atlantic Ocean. Indeed the satellite tracking data of the individual that left the Mediterranean Sea (TAG 10842) revealed that this fin whale migrated to the Atlantic Ocean along the Spanish coastline (Fig. 6). In addition to satellite tracking that allows precise location of individual fin whales over relatively short periods of time (mo), the stable isotopes measured along the baleen plates provide an insight on the main foraging regions over long-term periods (Hobson et al. 2004). However, precise reconstructions depend on BP growth rate data. A first attempt at estimating growth rate on Mediterranean fin whale is made using BP3. The concomitant changes of both $\delta^{15} \mathrm{~N}$ and $\delta^{13} \mathrm{C}$ between 20.5 and $17.6 \mathrm{~cm}$ on BP3 (Figs. 2 \& 3) could result from a shift in trophic level due to prey change or correspond to the weaning transition period from maternal milk to prey (Hobson \& Schell 1998, Hobson \& Sease 1998). Though small isotopic changes are observed $(\sim 1 \%)$, our $\delta^{13} \mathrm{C}$ shifts and depleted $\delta^{15} \mathrm{~N}$ observed at $\sim 20.5 \mathrm{~cm}$ might suggest weaning age $(7 \mathrm{mo}$ in fin whales; International Union for Conservation of Nature (IUCN) 1991) was reached, the juvenile shifting to nutritional independence and feeding at a lower trophic level than adults (Jenkins et al. 2001). However there is a very real possibility that some substantial, unknown amount of wear may have occurred for BP3, suggesting that the calculated growth rate of $20.1 \mathrm{~cm} \mathrm{yr}^{-1}(32.2-20.5 \mathrm{~cm}=$ $11.7 \mathrm{~cm} / 7 \mathrm{mo} \times 12 \mathrm{mo} \mathrm{yr}^{-1}$ ) correspond to a lowerlimit growth rate for this female BP3-BP4. Interestingly, BP3 growth rate $\left(\sim 20 \mathrm{~cm} \mathrm{yr}^{-1}\right)$ is within the range of those observed for adult Minke whales (12.9 $\mathrm{cm} \mathrm{yr}^{-1}$; Mitani et al. 2006); bowhead whales (20 $\mathrm{cm} \mathrm{yr}^{-1}$ or less; Schell et al. 1989a,b), and southern right whales $\left(2.7 \mathrm{~cm} \mathrm{yr}^{-1}\right.$; Best \& Schell 1996). Applying our minimum growth rate estimate, BP3 whale would be $\sim 1.6$ yr old. Because fin whales are believed to reach sexual maturity at $\sim 6$ to $12 \mathrm{yr}$, it is likely that the baleen of the adult female BP3 (Table 1) did in fact experience significant erosion at the distal end; otherwise the length of the baleen for a whale of at least $6 \mathrm{yr}$ of age should have been $\sim 120 \mathrm{~cm}$ at a minimum. In conclusion, it is likely that erosion would cause the underestimation of BP3 baleen growth rates, and hence this estimate is to be viewed as a minimum growth rate value. Using the minimum growth rate value $\left(20 \mathrm{~cm} \mathrm{yr}^{-1}\right)$, the multi $\delta^{13} \mathrm{C}$ cycles observed on BP10 and BP8 suggest that these individuals were regularly alternating between different foraging grounds, with individuals travelling once or twice a year from the Mediterranean Sea in the direction of the Atlantic Ocean, and we speculate these whales remained in the Gibraltar StraitAtlantic continuum.

A $3 \%$ order enrichment is expected between the $\delta^{15} \mathrm{~N}$ signature of Meganyctiphanes norvegica and fin whales if the whales are feeding exclusively on this prey. We found an enrichment of 2.6 to $3.5 \%$ (mean $\pm \mathrm{SD}=3.2 \pm 0.8$ ) between Mediterranean krill and baleen plates, and 0.2 to $1.8 \%$ between Atlantic krill and baleen plates. If $M$. norvegica was the yearround predominant prey of our study of fin whale populations, the observed $\delta^{15} \mathrm{~N}$ oscillations should primarily reflect migratory patterns or seasonal change in krill $\delta^{15} \mathrm{~N}$ signature. Furthermore, our krill data show an increase of 0.9 to $1.6 \%$ during spring to late summer transition in the Mediterranean Sea and Atlantic Ocean, respectively. Similarly Bode \& 
Alvarez-Ossorio (2004) reported a zooplankton $\delta^{15} \mathrm{~N}$ increase by more than $3 \%$ during the spring-summer transition, partly due to the nitrate depletion during phytoplankton growth. According to that hypothesis, and considering a $3.4 \% \delta^{15} \mathrm{~N}$ enrichment per trophic level, most fin whales in the present study could have only fed on krill in Atlantic in winter when krill $\delta^{15} \mathrm{~N}$ is depleted. However the geographical source given by the $\delta^{13} \mathrm{C}$ does not support that hypothesis (see also the following 2 subsections).

However, an enrichment of $<3.4 \%$ was suggested in several studies (Ostrom et al. 1993, Abend \& Smith 1997). An $2.4 \%$ enrichment factor for the $\delta^{15} \mathrm{~N}$ would lead to different interpretations of the migration pattern. For instance BP1 and BP2 $\delta^{15} \mathrm{~N}$ values would suggest the ingestion of only Atlantic krill and many values of the other BPs would indicate that whales feed on both Mediterranean Sea and Atlantic Ocean. Again the geographical source given by the $\delta^{13} \mathrm{C}$ does not corroborate such a scenario.

Hence potential mechanisms of decoupling carbon and nitrogen isotope signatures should be suggested. According to Hobson et al. (2004), migration and fasting could be such a mechanism. If whales migrate in winter and fast in Atlantic waters, highest $\delta^{15} \mathrm{~N}$ are expected, and carbon from stored fats is used for baleen formation. It might show that Mediterranean summer diet $\delta^{13} \mathrm{C}$ values determine the long-term substrate values for baleen formation. These hypotheses imply that Balaenoptera physalus has a wellidentified fasting period during winter. To our knowledge, no pattern of seasonal period of fasting has been reported in the literature.

Minagawa \& Wada (1984) found a 3.4\%o enrichment factor for $\delta^{15} \mathrm{~N}$ when using whole crustacean, as was the case in the present study. Furthemore, Hobson et al (1996) found a mean value of 3\% enrichment factor for $\delta^{15} \mathrm{~N}$ between the prey and keratinous tissues such as whiskers, nails, and hair. We might expect a similar enrichment factor between the whole krill prey and keratinous baleen plates of fin whales. Hence we suggest that a $3.4 \%$ enrichment factor is close to the actual number and believe that Meganyctiphanes norvegica is the predominant prey of this population of fin whales; therefore it follows that the observed stable isotope oscillations of BP10 and 8 primarily reflect migratory patterns.

We cannot exclude that Mediterranean fin whales are also feeding on other unknown prey species. According to Canese et al. (2006), zooplankton sampling collected in winter near Lampedusa, where fin whales fed, indicates the presence of Nyctiphanes couchi. However we can rule out that Mediterranean fin whales mainly feed on small mesopelagic fishes such as sardines or anchovies, as the whales occupy the same mean trophic level as these fish species (mean $\delta^{15} \mathrm{~N}$ ranging from 7.69 to 7.87 ; Pinnegar et al. 2003).

Nonetheless, higher $\delta^{15} \mathrm{~N}$ values were exhibited in BP1, suggesting that part of this whale's diet could be composed of prey from higher trophic levels over extended periods of time. However, taking into account the year of stranding (1975), the BP1 $\delta^{15} \mathrm{~N}$ values can also suggest that the nitrogen isotopic signature at the base of the food chain was higher $27 \mathrm{yr}$ ago.

Pinnegar et al. (2003) and Pauly et al. (1998) reported a decline in the mean trophic level of landings for the western Mediterranean Sea and interpreted it as 'fishing down the marine food web', mostly through diversification and (or) substitution in the species being targeted (marketed), as might be expected where the supply of the preferred target species has begun to dwindle (Pinnegar et al. 2002). In addition to this decline, the temporal decrease in $\delta^{13} \mathrm{C}$ and $\delta^{15} \mathrm{~N}$ may also provide some evidence of significant environmental changes affecting the Mediterranean Sea.

Schell (2000) reported a depletion of $\delta^{13} \mathrm{C}$ in Balaena mysticetus plates from the Bering Sea between 1947 and 1997. The $\delta^{13} \mathrm{C}$ depletion of the Bering Sea whales $\left(-0.05 \% \mathrm{yr}^{-1}\right)$ during the last $30 \mathrm{yr}$ is about twice as much as the one previously reported for the Indian Ocean (-0.02 $\mathrm{yr}^{-1}$; Gruber et al. 1999) and the one found in the plates from the Mediterranean fin whales in the present study $\left(-0.02 \% \mathrm{yr}^{-1}\right)$ between 1975 and 2002. The $\delta^{13} \mathrm{C}$ signature of the baleen plates over the study period suggests increasing $\delta^{13} \mathrm{C}$ values between 1975 and 1980 and 1996 and 2002, and decreasing $\delta^{13} \mathrm{C}$ between 1980 and 1996 (Fig. 5). Interestingly, Demirov \& Pinardi's (2002) simulations of the interannual surface Mediterranean circulation from 1979 to 1993 identify 2 periods, 1981 to 1987 and 1988 to 1993 , which differ in precipitation and winter wind regimes. Moreover, Conversi et al (2010) show important changes of the plankton at the end of the 1980s in the Mediterranean basins and provide analyses linking local, regional, and basin scale hydrological properties with 2 major indicators of large scale climate, the North Atlantic Oscillation (NAO) index and the Northern Hemisphere Temperature index, suggesting that the Mediterranean shift is part of a larger scale change affecting the northern hemisphere.

The driving force explaining the general carbon isotopic depletion patterns may reflect global hemispheric changes. Schell (2000), assuming constant 
dissolved $\mathrm{CO}_{2}$ concentration, attributed the $\delta^{13} \mathrm{C}$ depletion in the Bering Sea to a 30 to $40 \%$ decrease in the marine productivity. An alternative hypothesis was proposed by Cullen et al. (2001) who suggested that increased $\mathrm{CO}_{2}$ levels could also explain the $\delta^{13} \mathrm{C}$ depletion. Indeed, the atmospheric $\mathrm{CO}_{2}$ levels increased significantly due to fossil fuel burning, land changes, and cement manufacture (IPCC 2007) all resulting in a significant decrease of the $\delta^{13} \mathrm{C}_{\text {atmosphericCO2 }}$ (Keeling et al. 2001). However, in a recent study, Williams et al. (2011) interpreted the $\delta^{13} \mathrm{C}$ shift of the Bering Sea as a response to the increased upwelling intensity linked to the Aleutian low intensification.

In region off the upwelling the ${ }^{13} \mathrm{C}$ depleted atmospheric anthropogenic $\mathrm{CO}_{2}$ is partially absorbed by the ocean surface waters, thus decreasing the isotopic composition of the marine inorganic carbon pool. Known as the Suess effect (Gruber et al. 1999, Tanaka et al. 2003), this anthropogenic $\mathrm{CO}_{2}$ input affects the isotopic signature of primary producers and consequently of marine food web, thus possibly explaining in part the observed baleen plate $\delta^{13} \mathrm{C}$ shift noted herein.

Higher marine $\mathrm{CO}_{2}$ content may favour the photosynthetic rate, but such conditions would lead to a $\delta^{13} \mathrm{C}$ decrease and $\delta^{15} \mathrm{~N}$ increase (predominance of assimilatory nitrate reduction increases phytoplankton $\delta^{15} \mathrm{~N}$ ). This phenomenon has a direct effect on the isotopic signature of primary producers and consequently on the marine food web, explaining the baleen plate $\delta^{13} \mathrm{C}$ shift evidenced on a global scale (Cullen et al. 2001). However, the present $\delta^{15} \mathrm{~N}$ values $\left(-0.07 \% \mathrm{yr}^{-1}\right)$ were as significantly depleted as those observed in the Bering Sea $\left(-0.06 \% \mathrm{yr}^{-1}\right.$; see Schell 2000 and comment by Cullen et al. 2001). This decrease in $\delta^{15} \mathrm{~N}$ is intriguing, but poorly documented as an ecosystem indicator (Lee et al. 2005).

Atmospheric $\mathrm{N}_{2}$ would be used as a nitrogen source for primary production (diazotrophy), otherwise the microbial loop system may become more active, recycling isotopically light $\mathrm{NH}_{4}{ }^{+}$used by phytoplankton. However, the most likely mechanism to explain such a rapid change in the Mediterranean Sea would be a major shift of the nutrient balance in response to increased anthropogenic input by coastal run off, river discharge and atmospheric nitrogen compounds. Though additional nitrate may stimulate the biological pump, especially for the Mediterranean Sea, which is often considered as a nitrate depleted sea, this anthropogenic forcing can also significantly decrease the productivity of the ecosystem by altering the Redfield ratios (increase of the N:P and decrease of the Si:N ra- tios; Béthoux et al. 2002) and consequently modify the marine community (Turner et al. 2003). Data from the Gulf of Lions shows an N enrichment with respect to $P$ due to the Rhone River influence (Diaz et al. 2001). The changes in N:P:Si ratios observed since the early 1960s (Béthoux et al. 2002) could lead to a decreased photosynthetic rate or a phytoplankton shift from a diatom-dominated ecosystem towards a non-siliceous one and a more 'regeneration-dominated' community (Marty et al. 2002).

Superimposed on this declining trend, the potential impact of the decadal changes of the NAO cannot be ruled out, causing drier (normal) Mediterranean conditions during the negative (positive) phase. Since 1980, except in 1996, the NAO has been positive. As a result, the isotopic decline between 1980 and 2002 cannot be attributed to the NAO alone. A complex combination of circulation alteration, temperature increase (Goffart et al. 2002, Conversi et al. 2010) and nutrient availability, anthropogenic impact are likely affecting marine communities of the Mediterranean sub-basins.

The combination of satellite tracking and stable isotope signature methods reveals some major aspects of Mediterranean fin whale foraging, indicating that most individuals might be year-round residents of the northwestern Mediterranean Sea and that the largest predator of the Mediterranean Sea has a trophic level equivalent to that of anchovies and sardines.

The observed decrease in $\delta^{15} \mathrm{~N}$ is an important ecosystem indicator supporting the assumption of a changing nitrogen cycle with still unclear effects (Duce et al. 2008). More efforts need to be directed toward understanding the nitrogen biogeochemical cycle. Conversely, the change in $\delta^{13} \mathrm{C}$ reported is consistent with previously well-described studies. The decrease in primary production level or shifts in the primary producers are likely to influence the Mediterranean food web and consequently fin whales. However, the long term consequences remain unknown.

Acknowledgements. This research was supported through grants from the Office of Naval Research, awards N0014-021-0885 and N0-176A, and by the Ministère de l'Environnement et du développement durable Direction Nature \& Paysage (Parc National de Port-Cros). We thank the Centre de Recherche sur les Mammifères Marins and 'French stranding network' and the Centro de Recuperación de Especies Marinas Amenazadas de Andalucía (CREMA); J. M. Bompard, J. L. Fabre, and J. Salazar, who provided baleen plates; L. Irvine and M. L. Mate for field assistance during tag deployment, T. Follett for figure preparation; and Y. Cherel and G. Boehlert for their comments on earlier manuscript drafts. We thank the 2 anonymous reviewers who 
contributed to the significant improvement of this paper. We thank A. Chepstow-Lusty, N. Barrett and J. C Duplessy for their valuable feedback and Franck Ferraton for Mediterranean krill isotopic composition support. The Comité National de la Recherche Scientifique (CNRS) Ethic Committee and Ohio State University-Institutional Animal Care and Use Committee (OSU-IACUC) approved this research. This is ISE-M contribution no. ISEM 2011-081.

\section{LITERATURE CITED}

$>$ Abend AG, Smith TD (1997) Differences in stable isotope ratios of carbon and nitrogen between long-finned pilot whales (Globicephala melas) and their primary prey in the western north Atlantic. ICES J Mar Sci 54:500-503

Aïssi M, Celona A, Comparetto G, Mangano R, Wurtz M, Moulins A (2008) Large-scale seasonal distribution of fin whales (Balaenoptera physalus) in the central Mediterranean Sea. J Mar Biol Assoc UK 88:1253-1261

> Bailleul F, Authier M, Ducatez S, Roquet F, Charrassin JB, Cherel Y, Guinet C (2010) Looking at the unseen: combining animal attached remote sensing and stable isotope analyses for monitoring the foraging behaviour of a deep diving predator. Ecography 33:709-719

> Bearhop S, Adams CE, Waldron S, Fuller RA, MacLeod H (2004) Determining trophic niche width: a novel approach using stable isotope analysis. J Anim Ecol 73:1007-1012

- Bentaleb I, Fontugne M, Descolas-Gros C, Girardin C and others (1998) Carbon isotopic fractionation by plankton in the southern Indian Ocean: relationship between $\delta^{13} \mathrm{C}$ of particulate organic carbon and dissolved carbon dioxide. J Mar Syst 17:39-58

Bérubé M, Aguilar A, Dendanto D, Larsen F and others (1998) Population genetic structure of North Atlantic, Mediterranean Sea and Sea of Cortez fin whales, Balaenoptera physalus (Linnaeus 1758): analysis of mitochondrial and nuclear loci. Mol Ecol 7:585-599

Best PB, Schell DM (1996) Stable isotopes in southern right whale (Eubalaena australis) baleen as indicators of seasonal movements, feeding and growth. Mar Biol 124: 483-494

Béthoux JP, Morin P, Ruiz-Pino DP (2002) Temporal trends in nutrient ratios: chemical evidence of Mediterranean ecosystem changes driven by human activity. Deep-Sea Res II 49:2007-2016

> Bode A, Alvarez-Ossorio MT (2004) Taxonomic versus trophic structure of mesozooplankton: a seasonal study of species succession and stable carbon and nitrogen isotopes in a coastal upwelling ecosystem. ICES J Mar Sci 61:563-571

- Canese S, Cardinali A, Fortuna CM, Giusti M, Lauriano G, Salvati E, Greco S (2006) The first identified winter feeding ground of fin whales (Balaenoptera physalus) in the Mediterranean Sea. J Mar Biol Assoc UK 86:903-907

> Cherel Y, Hobson KA (2007) Geographical variation in carbon stable isotope signatures of marine predators: a tool to investigate their foraging areas in the Southern Ocean. Mar Ecol Prog Ser 329:281-287

> Cherel Y, Hobson KA, Guinet C, Vanpe C (2007) Stable isotopes document seasonal changes in trophic niches and winter foraging individual specialization in diving predators from the southern ocean. J Anim Ecol 76:826-836

Conversi A, Fonda Umani S, Peluso T, Molinero JC and others (2010) The Mediterranean Sea regime shift at the end of the $1980 \mathrm{~s}$, and intriguing parallelisms with other Euro- pean basins. PLoS ONE 5:e10633. doi:10.1371/journal. pone.0010633

Cotté C, Guinet C, Taupier Letage I, Mate B, Petiau E (2009) Scale-dependent habitat use by a large free-ranging predator, the Mediterranean fin whale. Deep-Sea Res I 156:801-811

Cullen JT, Rosenthal Y, Falkowski PG (2001) The effect of anthropogenic $\mathrm{CO}_{2}$ on the carbone isotope composition of marine phytoplankton. Limnol Oceanogr 46:996-998

$>$ Demirov E, Pinardi N (2002) Simulation of the Mediterranean Sea circulation from 1979 to 1993. I. The interannual variability. J Mar Syst 33:23-50

> DeNiro MJ, Epstein S (1978) Influence of diet on the distribution of carbon isotopes in animals. Geochim Cosmochim Acta 42:495-506

DeNiro MJ, Epstein S (1981) Influence of diet on the distribution of nitrogen isotopes in animals. Geochim Cosmochim Acta 45:341-351

> Diaz F, Raimbault P, Boudjellal B, Garcia N, Moutin T (2001) Early spring phosphorus limitation of primary productivity in a NW Mediterranean coastal zone (Gulf of Lions). Mar Ecol Prog Ser 211:51-62

- Duce RA, LaRoche J, Altieri K, Arrigo KR and others (2008) Impacts of atmospheric anthropogenic nitrogen on the open ocean. Science 320:893-897

Ferraton F (2007) Écologie trophique des juvéniles de merlu (Merluccius merluccius) dans le golfe du Lion: Implications biologiques de la variabilité spatio-temporelle des ressources alimentaires exploitées dans les zones de nourricerie. $\mathrm{PhD}$ thesis, l'Université Montpellier II

Forcada J, Aguilar A, Hammond P, Pastor X, Aguilar R (1996) Distribution and abundance of fin whales (Balaenoptera physalus) in the western Mediterranean Sea during the summer. J Zool (Lond) 238:23-24

Goffart A, Hecq JH, Legendre L (2002) Changes in the development of the winter-spring phytoplankton bloom in the Bay of Calvi (northwestern Mediterranean) over the last two decades: a response to the changing climate? Mar Ecol Prog Ser 235:387-399

Gruber N, Keeling CD, Bacastow RD, Guenther PR and others (1999) Spatiotemporal patterns of carbon-13 in the global surface oceans and the oceanic Suess effect. Global Biogeochem Cycles 13:307-335

Heide-Jørgensen MD, Kleivane L, Øien N, Laidre, Villum Jensen M (2001) A new technique for deploying satellite transmitters on baleen whales: tracking a blue whale (Balaenoptera musculus) in the north Atlantic. Mar Mamm Sci 17:949-954

Hobson KA, Schell DM (1998) Stable carbon and nitrogen isotope patterns in baleen from eastern Arctic bowhead whales (Balaena mysticetus). Can J Fish Aquat Sci 55: 2601-2607

> Hobson KA, Sease JL (1998) Stable isotope analyses of tooth annuli reveal temporal dietary records: an example using Steller sea lions. Mar Mamm Sci 14:116-129

> Hobson KA, Schell DM, Renouf D, Noseworthy E (1996) Stable carbon and nitrogen isotopic fractionation between diet and tissues of captive seals: implication for dietary reconstructions involving marine mammals. Can J Aquat Sci 53:528-533

> Hobson KA, Riget FF, Outridge PM, Dietz R, Born E (2004) Baleen as a biomonitor of mercury content and dietary history of North Atlantic minke whales (Balaenopetra acutorostrata): combining elemental and stable isotope approaches. Sci Total Environ 331:69-82 
IPCC (2007) Fourth assessment report (AR4), climate change 2007: the physical science basis. Contribution of working group I to the fourth assessment report of the intergovernmental panel on climate change. Cambridge and New York

IUCN (1991) Dolphins, porpoises and whales of the world. Klinowska M (Compiler) Gland and Cambridge

Jenkins SG, Partridge ST, Stephenson TR, Farley SD, Robbins CT (2001) Nitrogen and carbon isotope fractionation between mothers, neonates, and nursing offspring. Oecologia 129:336-341

Kaschner K, Stergiou KI, Weingartner G, Kumagai S (2004) Trophic levels of marine mammals and overlap in resource utilization between marine mammals and fisheries in the Mediterranean Sea. In: Briand F (ed) Investigating the role of cetaceans in marine ecosystems. CIESM Workshop Monographs 25:51-58

Keeling C, Piper S, Bacastow R, Wahlen M, Whorf $T$, Heimann M, Meijer H (2001) Exchanges of atmospheric $\mathrm{CO}_{2}$ and ${ }^{13} \mathrm{CO}_{2}$ with the terrestrial biosphere and oceans from 1978 to 2000. I. Global aspects. Scripps Institution of Oceanography (SIO) reference series, no. 01-06, San Diego, CA

Kelly JF (2000) Stable isotopes of carbon and nitrogen in the study of avian and mammalian trophic ecology. Can J Zool 78:1-27

Kiljunen M, Grey J, Sinisalo T, Harrod C, Immonen H, Jones RI (2006) A revised model for lipid-normalizing $\delta^{13} \mathrm{C}$ values from aquatic organisms, with implications for isotope mixing models. J Appl Ecol 43:1213-1222

Lee SH, Schell DM, McDonald TL, Richardson WJ (2005) Regional and seasonal feeding by bowhead whales Balaena mysticetus as indicated by stable isotope ratios. Mar Ecol Prog Ser 285:271-287

Marty JC, Chiaverini J, Pizay MD, Avril B (2002) Seasonal and interannual dynamics of nutrients and phytoplankton pigments in the western Mediterranean Sea at the DYFAMED time-series station (1991-1999). Deep-Sea Res II 49:1965-1985

McConnaughey T, McRoy CP (1979) Food-web structure and the fractionation of carbon isotopes in the Bering Sea. Mar Biol 53:257-262

> McCutchan JH, Lewis WM, Kendall C, McGrath CC (2003) Variation in trophic shift for stable isotope ratios of carbon, nitrogen, and sulfur. Oikos 102:378-390

> Minagawa M, Wada E (1984) Stepwise enrichment of $\delta^{15} \mathrm{~N}$ along food chains: further evidence and relation between $\delta^{15} \mathrm{~N}$ and animal age. Geochim Cosmochim Acta 48: $1135-1140$

Mitani Y, Bando T, Takai N, Sakamoto W (2006) Patterns of stable carbon and nitrogen isotopes in the baleen of common minke whale Balaenoptera acutorostrata from the western north Pacific. Fish Sci 72:69-76

Monestiez P, Dubroca L, Bonin E, Durbec JP, Guinet C (2006) Statistical modelling of spatial distribution of Balaenoptera physalus in the northwestern Mediterranean Sea from sparse count data and heterogeneous observation effort. Ecol Modell 193:615-628

Notarbartolo di Sciara G, Zanardelli M, Jahoda M, Panigada S, Airoldi S (2003) The fin whale Balaenoptera physalus (L. 1758 ) in the Mediterranean Sea. Mammal Rev 33:105-150

O'Connell TC, Hedges REM (1999) Investigations into the effect of diet on modern human hair isotopic values. Am Jour Phys Anth 108:409-425

Orsi Relini L, Giordano A (1992) Summer feeding of the fin whales, Balaenoptera physalus, in the liguro Provençal Basin. Eur Res Cetac 6:138-141

> Ostrom PH, Lien J, Macko SA (1993) Evaluation of the diet of Sowerby's beaked whale, Mesoplodon bidens, based on isotopic comparisons among northwestern Atlantic cetaceans. Can J Zool 71:858-861

> Panigada S, Pesante G, Zanardelli M, Capoulade F, Gannier A, Weinrich M (2006) Mediterranean fin whales at risk from fatal ship strikes. Mar Pollut Bull 52:1287-1298

Pauly D, Christensen V, Dalsgaard J, Froese R, Torres F (1998) Fishing down marine food webs. Science 279: 860-863

Peterson BJ, Fry B (1987) Stable isotopes in ecosystem studies. Annu Rev Ecol Syst 18:293-320

> Pinnegar JK, Jennings S, O'Brien CM, Polunin NVC (2002) Long-term changes in the trophic level of the Celtic Sea fish community and fish market price distribution. J Appl Ecol 39:377-390

Pinnegar JK, Polunin NVC, Badalamenti F (2003) Long-term changes in the trophic level of western Mediterranean fishery and aquaculture landings. Can J Fish Aquat Sci 60:222-235

> Post DM (2002) Using stable isotopes to estimate trophic position: models, methods, and assumptions. Ecology 83: 703-718

Post DM, Layman CA, Arrington DA, Takimoto G, Quattrochi J, Montaña CG (2007) Getting to the fat of the matter: models, methods and assumptions for dealing with lipids in stable isotope analyses. Oecologia 152:179-189

R Development Core Team (2010) R: a language and environment for statistical computing. R Foundation for Statistical Computing, Vienna, Austria. ISBN 3-900051-07-0, www.R-project.org/.

Rau GH, Takahashi T, Des Marais DJ (1989) Latitudinal variations in plankton $\delta^{13} \mathrm{C}$ : implications for $\mathrm{CO}_{2}$ and productivity in past oceans. Nature 341:516-518

Raymont JEG, Srinivasagam RT, Raymont JKB (1971) Biochemical composition of zooplankton. VIII. Further investigations on Meganyctiphanes norvegica (M. Sars). Deep-Sea Res 18:1167-1178

Ruchonnet D, Boutoute M, Guinet C, Mayzaud P (2006) Fatty acid composition of Mediterranean fin whale Balaenoptera physalus blubber with respect to body heterogeneity and trophic interaction. Mar Ecol Prog Ser 311: 165-174

Salomon M, Mayzaud P, Buchholz F (2000) Studies on metabolic properties in the northern krill, Meganyctiphanes norvegica (Crustacea, Euphausiacea): influence of nutrition and season on pyruvate kinase. Comp Biochem Physiol 127:505-514

Sanpera C, Aguilar A (1992) Modern whaling off the Iberian Peninsula during the 20th century. Rep Int Whal Comm 42:723-730

Schell DM (2000) Declining carrying capacity in the Bering Sea: isotopic evidence from whale baleen. Limnol Oceanogr 45:459-462

Schell DM, Saupe SM, Haubenstock N (1989a) Bowhead whale (Balaena mysticetus) growth and feeding as estimated by $\delta^{13} \mathrm{C}$ techniques. Mar Biol 103:433-443

Schell DM, Saupe SM, Haubenstock N (1989b) Natural isotope abundances in bowhead whale (Balaena mysticetus) baleen: markers of aging and habitat usage. Ecol Stud 68:260-269

Tanaka T, Watanabe YW, Watanabe S, Noriki S, Tsurushima N, Nojiri Y (2003) Oceanic Suess effect of $\delta 13 \mathrm{C}$ in sub- 
polar region: the north Pacific. Geophys Res Lett 30: 2159-2162 doi:10.1029/2003GL018503

Turner RE, Rabalais NN, Justic D, Dortch Q (2003) Future aquatic nutrient limitations. Mar Pollut Bull 46:1032-1034

> Vander Zanden MJ, Rasmussen JB (2001) Variation in $\delta^{15} \mathrm{~N}$ and $\delta^{13} \mathrm{C}$ trophic fractionation: implications for aquatic food web studies. Limnol Oceanogr 46:2061-2066

> Vanderklift A, Ponsard S (2003) Sources of variation in consumer-diet $\delta^{15} \mathrm{~N}$ enrichments: a meta-analysis. Oecologia 136:169-182

Editorial responsibility: John Piatt, Anchorage, Alaska, USA
Wada E, Mizutani H, Minagawa M (1991) The use of stable isotopes for food web analysis. Crit Rev Food Sci Nutr 30:361-371

Wilks D (2006) Statistical methods in the atmospheric sciences, 2nd edn. Elsevier, Oxford

Williams B, Halfar J, Steneck RS, Wortmann UG and others (2011) Twentieth century $\delta^{13} \mathrm{C}$ variability in surface water dissolved inorganic carbon recorded by coralline algae in the northern North Pacific Ocean and the Bering Sea. Biogeosciences 8:165-174

Submitted: September 14, 2010; Accepted: June 18, 2011 Proofs received from author(s): September 10, 2011 